\title{
Hacia un cristianismo postmoderno
}

\section{REALIDADES BÁSICAS DEL MOMENTO ACTUAL}

-La era de la sociedad industrial ha terminado. El hombre no es para la producción sino la producción para el hombre. Se rechaza así el modelo productivo masificador de la sociedad industrial tradicional, en Occidente y en el Este (A. Toffler, La tercera ola), que ha constituido Europa. La disolución de Occidente ha comenzado ${ }^{1}$. También la del Este.

1. La producción como realidad central de la vida y la sociedad industrial se disuelve: BAudRILlaRd, , J., El espejo de la producción. Trad. castellana de Gedisa, Barcelona 1980. Alvin Toffler también ha subrayado que el problema no es capitalismo o marxismo sino producción o qué. Es La tercera ola. Ahora Nietzsche ya no es discutible, todos lo vemos con nuestros propios ojos: «¿Cómo es posible que todo amenace ruina? ¿Cómo se encuentra reducido a escombros lo que los filósofos consideraban más duradero que el bronce? iQué equivocada es, desgraciadamente, la respuesta que se sigue dando a esta pregunta!: que 'todos se olvidaron de cuestionar las hipótesis, de examinar el fundamento, de someter a crítica a toda la razón'»: NiETzSCHE, F., Aurora. Reflexiones sobre la moral como prejuicio. Traducción castellana de E. López Castellón, PP.P.S.A. Madrid 1984, 29, prólogo n, 3. Es la más profunda crisis de Europa «como forma de vida espiritual». En segundo lugar la forma de esta crisis caracterizada como nihilismo hace presagiar una futura transmutación de todos los valores, el hundimiento de nuestro paradigma cultural y la emergencia de otro radicalmente nuevo, en el que habrá desaparecido 'el hombre' (como objeto y sujeto del saber), hombre abstracto y atomizado del humanismo burgués. No es otro el sentido que tiene para Foucault, la promesa - amenaza del superhombre- el hombre 'superado'»: MoRey, M., Lectura de Foucault. Taurus, Madrid 1983, 22. De este modo en la postmodernidad todo es inestabilidad. La postmodernidad tiene que investigar constantemente sobre situaciones o sistemas inestables (LYOTARD, 106). Ahora el sistema es inestable (Ib., 106). Y lo mismo en los ideales: «Simplificando al máximo, se tiene por 'postmoderna' la incredulidad con respecto a los metarrelatos. Ésta es, sin duda, un efecto del progreso de las ciencias; pero, ese progreso, a su vez, la presupone»: LyotARD, J.F., La condición postmoderna, Madrid 1984,10. Todo esto debe entenderse «sobre la base de un análisis de la postmodernidad que la tome en sus características propias, que la reconozca como campo de posibilidades y no la conciba sólo como el infierno de la negación de lo humano": VATTIMO, El fin de la modernidad, 19. No hay que vivir esta situación, por tanto, como un drama sino como una nueva posibilidad que Dios nos ofrece y que hemos de afrontar con lucidez: Ib., 57: «Nietzsche describió esta situación al oponer al hom- 
- Se ha terminado también la era de las ilusiones revolucionarias. La creencia en la revolución instantánea y en los cambios repentinos ya no existe como esperanza generalizada en la humanidad. Hoy crece la conciencia de que la revolución ha de ser necesariamente también una revolución ética o sencillamente no será. Se pretende un ser humano mucho más personalizado. Y esto se expresa diciendo que estamos en la caída del imperialismo (Roszak), e incluso del autoritarismo democrático.

-Tampoco tiene ya futuro el revolucionarismo violento, como forma de transformación de la realidad y en concreto de la sociedad. De este modo nos encontramos ante un mundo nuevo.

- Toca también a su fin la época de las grandes ideologías, y de las teorías globalizantes que enmascaran la realidad en vez de revelarla. Así ocurre con el marxismo y también con el cristianismo en cuanto se convierta en ideología o teoría utilitaria. La época de los grandes relatos ha terminado. Por eso se impone el pasar de las meras ideas a un mundo de vivencias auténticas y concretas, o no será posible llegar al hombre actual sólo con una fe muerta. Sólo se puede llegar a las personas por medio de personas y a las comunidades por medio de comunidades vivas. Lo demás es poesía... (E. Nuntiandi 21, 41, $60,69,72,76)$. Se trata de una nueva forma de pensar, de vivir, y de actuar sobre la realidad. Hay una crisis global de valores y de formas vitales. Se tiene la impresión de que lo que antes valía ahora no vale. Así nos encontramos ante una crisis de identidad, ante una gran falta de confianza en la comunidad (Greinacher) y con poca esperanza en el sentido de la misión y el destino de la humanidad.

En general se puede señalar una gran falta de sensibilidad hacia las personas, hacia la solidaridad y hacia el sentido de la realidad; se podría decir que estamos ante una gran anemia emocional y ante una desubstancialización de ia realidad (Lipovetsky) a todos los niveles. Ante esta situación es necesario

\footnotetext{
: todavía resentido que vive como un drama la pérdida de las dimensiones patéticas, metafísias, de la existencia, el hombre de buen carácter, que está 'libre del énfasis'». La cosa se presenta más o menos así; es como «el estallido de los grandes relatos: instrumentos de la igualdad y de la emancipación del individuo liberado del terror de los megasistemas, de la uniformidad de lo verdadero y por ello a merced de la inestabilidad experimental y de los 'contratos temporales', en estrecha congruencia con la desestabilización y particularización del narcisismo. La denuncia del imperialismo de lo verdadero es una figura ejemplar del postmodernismo»: LIPOVETSKY, La era del vacío, 1987, $2^{\text {a }}, 114-115$. Es la caída de la fe en el progreso con sus referencias providenciales y metahistóricas (la providencia ya no es controlable-Lyotard), cae la fe triunfalista: «La disolución tiene que ver, por un lado, con el proceso mismo de secularización; en efecto, Gehlen dice que la secularización 'consiste en general en el hecho de que las leyes propias, específicas, del mundo nuevo sofocan la fe, o, mejor dicho, no tanto la fe como su certeza triunfalista (die siegesbeglückte Gewissheit)»: VAtTimo, G., El fin de la modernidad, Sedisa, Barcelona 1986, 94.
} 
emprender una recuperación a fondo de la identidad, de la intimidad, de las convicciones personales propias y, en definitiva, del individuo y de la persona de manera que se pueda comenzar a vivir de nuevo entre personas, de persona a persona, y no meramente como personal (Paul Goodmann). También debemos intentar una recuperación de la confianza en la comunidad, en la propia vocación que es también con-vocación, y solidaridad mediante un sentido real de los demás (Finkielkraut, P. Blanquart). Solamente así será posible recuperar también de nuevo la confianza en la misión de modo que no haya que decir con M. Kundera: nadie tiene ninguna misión.

Por lo demás nuestro mundo tiene más necesidad de ser persuadidoseducido que mandado (le muestras a un niño unas avellanas y le atraen - san Agustín-), nuestras gentes necesitan más de nuestra convicción que de nuestra imposición. Incluso hoy es aún más necesaria la convicción que el cumplimiento. Nuestro hombre se encuentra hoy ante un inmenso desierto (personal, social y universal), se ha roto el sentido y el contagio de la masa y la soledad acecha y asoma por todas partes, incluso en la comunidad. A su vez el mundo actual es enormemente narcisista y ombligista-individualista. Cada cual se centra irracionalmente en lo suyo y así pretende recuperar su vida, no ve que el que quiera retener su vida la perderá. A veces el hombre actual pretende amarse a sí mismo de tal manera que no necesite ser amado nunca de los demás. La consigna hoy se resume así: cada cual a su burbuja (Baudrillard) ${ }^{2}$.

En cualquier caso, necesitamos ser personas, no cosas, sujetos no objetos. Si hemos de amar al prójimo como a nosotros mismos pero realmente no nos amamos a nosotros mismos, entonces amar al prójimo como a sí mismo resultaría una gran ironía. En cuanto a la vida comunitaria y la misión, necesitamos dejar de ser camellos que llevan el largo fardo de la convivencia y la evangelización por el desierto, para convertirnos en creadores y alentadores de la propia empresa, desde la empresa común y la misión universal de la Iglesia en el mundo actual. Solamente así es posible superar la revolución inhumana, el dominio vigente y aparcar de una vez por todas las reverendas vaguedades insubstanciales.

2. Baudrillard, J., El otro por sí mismo. Anagrama, Barcelona 1988, 34: «Hoy la ley es: a cada cual su burbuja». Ib., 35: Anteriormente, la obsesión consistía en parecerse a los demás y perderse en la multitud. Obsesión de la conformidad, manía de la diferencia. Hace falta una solución que nos libre de parecernos a los demás. Hoy consiste en «parecerse únicamente a uno mismo». 


\section{ESTO ES LO QUE HAY}

Si este cambio no se produce en nosotros, seremos inevitablemente arrastrados por la situación actual que globalmente, y siguiendo a Lipovetsky, puede describirse así:

\section{Seducción sin parar}

El hombre pretende hacerse el dueño y el centro absoluto de la realidad ${ }^{3}$. La persona tiende a conducir todo hacia sí misma. Pretende ser insaciablemente el centro del mundo y del grupo y por tanto muestra un amor absoluto a todo lo que le refleja y obedece, y un rechazo sin límites a cuanto le molesta. Es un amor absoluto hacia sí mismo, lo demás no importa. Y no es que tratemos de engañar a los demás, sencillamente nos engañamos a nosotros mismos de tan buenos que nos creemos, pensamos y somos. Así la persona se ve mucho mejor de lo que es, rechaza siempre a quien le critica y por tanto no puede mejorar. Este proceso termina además en estrategias fatales porque crea en la persona la compulsión del propio espectáculo (Baudrillard), y esto lleva consigo: pérdida del sentido del prójimo, exacerbación del instinto de prestigio (Marvin Harris) por el que utilizo cuanto puedo a los demás sin reparar en miramiento alguno.

El defecto clave de esta situación es que la persona patina sobre sí misma y no es capaz de enganchar con la realidad. Esto produce y es producto de una anemia emocional o gran insensibilidad hacia los demás; finalmente se produce una desubstancialización de la vida y del sentido de la persona. La posibilidad positiva de esta situación sería: el intento fuerte de una recuperación de la propia identidad, poco a poco se trata de reencontrar a la propia persona, la

3. LipovetSKY, La era del vacío, 1987, 2. a . Hoy se busca el derecho a guiarse a sí mismo, a no ser conducido desde el exterior (Ib., 87) y casarse por amor (Ib. 89). Hay una desublimación general y «un trabajo de destitución de las alturas y majestades está en marcha» (Ib., 89), es una renuncia a la 'organización jerárquica' de las cosas, se revaloriza lo cotidiano y la dignidad de lo menor, es el homo aequalis (Ib. 90). El hedonismo es ahora el valor central: «En este sentido, el postmodernismo aparece como la democratización del hedonismo, la consagración generalizada de lo nuevo, el triunfo de lo 'anti-moral y del antiinstitucionalismo (D. Bell, 63), el fin del divorcio entre los valores de la esfera artística y los de lo cotidiano» (Ib. 105). Al ombligista sólo le importan sus problemas, se cree el centro del mundo: «El individualista no sueña sino consigo mismo, él no sueña al Otro» (ALERGET, J., L. et V., 36 (1987) 31. Así el cristianismo actual tiende a realizarse según el único criterio de 'se sentir bien', pero sin compromiso ni vida concreta. Se busca sobre todo la propia expansión: sincretismo, espectáculo, emoción, calor. La espiritualidad ya no es un fin: vivir para Dios, sino un medio del narcisismo propio: BLANQUART, P., L. et V. 36 (1987) 76 y 75 . 
intimidad perdida y sobre todo de ganarse unas convicciones propias y auténticas. Si esto falta viene:

\section{La indiferencia pura ${ }^{4}$}

Tan característica del mundo actual. La gente, como gran masa, ha desaparecido. En cierta manera ya no hay masa. La masa hace muy diversas cosas. En cierto modo, ya no puede llamarse masa. Esta situación produce un auténtico desierto humano aunque numéricamente haya mucha gente. Las mismas fiestas populares ya no tienen, como antes, objetivos comunes, cada cual va a lo suyo. Esta descomposición de la masa y la situación de indiferencia se produce, entre otras razones, por ciertas experiencias de desastres e insolidaridades que están muy generalizadas incluso a niveles mundiales. Entre ellas pueden enumerarse las siguientes: destrucción de naciones, ciudades y pueblos enteros (Hiroshima, Vietnam, etc.); desarraigo y éxodo rural y ciudadano; grandes accidentes, guerras o terremotos, etc. Lo cierto es que todo es desierto, vacío y desolación, no hay nada que valga la pena; el desierto cada día gana más espacio al mundo civilizado, se ve la gran potencia de lo negativo; además el trabajo cada vez tiene menos sentido y se parece más bien a un secuestro laboral; ya no hay trabajo en común.

Toda esta situación conduce a una desafección general a las instituciones, a los valores y a las finalidades que habían justificado la vida común en las épocas anteriores. El desierto crece así, cada vez más: en el saber-cienciaescuela, en el poder-política, en el trabajo y convivencia-sociedad, en el ejército, en la familia, en la Iglesia, en las congregaciones y sindicatos... Ya no se vive según principios generales ni estrategias globales-. En el trabajo, el absentismo laboral es cada vez más frecuente. El frenesí del fin de semana y de las vacaciones crece también sin cesar. Retirarse del trabajo es una de las aspiraciones más generales hoy día. La familia va por caminos muy semejantes: crece el divorcio, las generaciones diversas no se entienden, los viejos caminan al asilo, resignados, como mal menor. En cuanto al ejército baste decir que escapar hoy al servicio militar se considera casi un honor, como antes el ser valiente. En la Iglesia hay una gran crisis de confianza. El problema vocacional nos indica hasta qué punto tiene hoy sentido, para muchos, comprometerse definitivamente y con seriedad. Los sindicatos se encuentran, como los partidos, con grandes problemas de afiliación; y más aún, les resulta muy difícil manejar los procesos reivindicativos. Así en la última huelga de la enseñanza en España - mayo 1988 - vemos lo siguiente: los sindicatos firman un prea-

4. LipovetSKy, La era del vacío, Gallimard, 1985 (en francés) 39 y ss. 
cuerdo, pero los profesores no lo refrendan, entonces los sindicatos declaran huelga indefinida, pero los profesores no la siguen y aquéllos se ven obligados a desconvocar. En cuanto a actitudes generales hay que destacar el sentido del esfuerzo, cada vez tiene menos defensores y practicantes; lo que se lleva es en todo: mínimo esfuerzo y mínimo interés, que es una práctica miserabilista pero generalizada. Parece que el sentido de la fuerza de voluntad y el espíritu de sacrificio hubieran abandonado nuestro mundo.

En este desierto apático, las cosas que funcionan, vgr. en la sociedad, lo hacen a base de especialistas que son como los últimos sacerdotes de lo que queda de religión-solidaridad en nuestra época (Nietzsche); la vida se presenta así como un gran espacio vacío en las galaxias donde un conjunto de astronautas absolutamente independientes viajan en medio de un espacio en el que reina el frío de la indiferencia emocional y una enorme pesadumbre inhumana. Vivimos hoy la vida de los espacios sin afectos. Por eso es ahora más necesario que nunca recuperar a la persona viva, del hombre muerto con una vida personal, en la que se recupere el sentido de la misma, a fondo, para que luego pueda ir hacia los demás. El primer paso es, pues, cuidarse a sí mismo - paso fundamental - para recuperar la sensibilidad y el amor al prójimo desde la propia individualidad. (Lumière et Vie, 184 (1987) Aujourdhui l'individualisme) ${ }^{5}$.

Esta situación nos obliga a plantear hoy de nuevo el problema del individualismo sin reducirlo únicamente a la idea de egoísmo. Condenar sin más el individualismo actual en bloque nos quitaría toda posibilidad de redimirlo. Por tanto, actualmente, hay que intentar una nueva comprensión del individuo que le impida cerrarse solamente en puro egoísmo. Así el individualismo

5. Todo el número de Lumière et vie 184 (36) (1987) está dedicado al análisis del fenómeno actual del individualismo. En la editorial p. 4 se dice lo siguiente: «Porque la seducción individualista nace, al parecer, de una debilidad inherente al ser humano: no saber amarse sencillamente a sí mismo. Pero entonces qué sentido puede tener el amar al prójimo como a sí mismo » (trad. nuestra). Y algo de esto «Es ciertamente lo que sugiere Milosz: el individualismo, como último refugio - tangible, palpable- de una imaginación y de una razón desorientadas» (L. et V. 184 (1987) 24: SIMÓN, M., «L'individualisme au miroir de la philosophie contemporaine en France» (trad. nuestra). El individualismo también puede ser un día el individuo libre y responsable en una sociedad y estilo de vida donde cada cual es dueño de su destino (LAURENT, A., De l'individualisme. Enquête sur le retour de l'individu. Paris PUF 1985). Ib. 6. Es la persona que habla en nombre propio y tiene una vida personal interior, unificada y propia (Ib. 7), así lo entiende J.P. Vernant. Es el cristianismo mismo quien crea la persona (B. Henry-Levy,. M. Gauchet). Es el personalismo cristiano frente a esta otra moral que denuncia Nietzsche: «Se considera bueno todo lo que, de un modo u otro, responde a este instinto de agrupación (ser un gran cuerpo) y sus diversos subinstintos. Esta es la corriente fundamental de la moral de hoy, con la que se funden la simpatía y los sentimientos sociales». Aurora, M. 1984, 122. Esto ha destruido a las grandes personalidades (M. LEGAuT, Creer, 134). No hay que decir sin más que todo individualismo es desmovilizador, porque el nuevo movimiento estudiantil de 1987 lo desmiente. Lo mismo los jóvenes. 
actual debería comprenderse como un nuevo intento de un nuevo sistema de personalización. De ahora en adelante la persona tendrá que vivir por sí mis$m a$, sin esconderse en el propio refugio como el caracol. Cada uno tendrá que ganarse sus propias convicciones. Así esta sociedad nueva, individualista, que nosotros preferimos llamar personalista, tendrá que hacer posible la constitución de una identidad propia que no puede dictarse desde fuera y donde cada uno tiene que ver cómo puede hacerse, sentirse y creerse. Cada persona tiene que enfrentarse con la propia situación y decidir ella lo que ha de vivir; no puede vivir de prestado o de la vida ajena como ha sido tan frecuente. Por eso hoy no vale disolverse en la comunidad. Ahora cada cual ha de romper un poco, o un mucho, con su rutina y hacer realmente él mismo las cosas. La comunidad es algo que hay que recuperar después, una vez recuperada la persona. Este planteamiento es fundamental en el pensamiento actual, débil, posmoderno. Sin esa identidad actual, la persona se esfuma y se disipa. Y entonces ya no es posible hacer realmente nada; nos falta el hombre. Esto nos advierte de por qué han caído tanto las euforias políticas y está, en cambio, en alza, la aceptación de grupos cívicos de convivencia, y, en nuestro caso, por qué aumentan los grupos de oración mientras se rechazan los grandes discursos teológicos.

Hay que darse cuenta, por tanto, de la necesidad de cultivar la dimensión íntima de la fe y no hacer una religión puramente fría y fraternalmente anémica. Por eso adquiere cada vez mayor importancia la experiencia personal de la fe y de la oración en el cristianismo actual.

Ciertamente la persona, al cultivar esa intimidad corre un grave peligro de caer en el narcisismo. Así se crea una crisis suplementaria en la oración. No es ya sólo el miedo al esfuerzo y la conversión o la mitología del trabajo profesional sino que el egoísmo oracional deja a la fe ayuna de compromiso y la vuelve absolutamente increíble. El verdadero individualismo-personalismo nos debería llevar a amar al prójimo como a uno mismo, pero si uno no se ama realmente a sí mismo o se ama realmente mal a sí mismo, entonces amar al prójimo como a sí mismo será un cinismo egoísta y ridículo. Así vemos cómo la kenosis -el anonadamiento-, a ejemplo de Cristo, es imprescindible para la misión (Filipenses 2,3-11).

En cuanto al problema del desierto y la indiferencia, tenemos que acostumbranos a enfrentarnos con nuestra propia soledad. Darnos cuenta que es una tarea absolutamente imprescindible de la que no podemos huir. Solamente así podemos encontrarnos realmente con nosotros mismos y trabajar por conseguir un nivel fundamental de convicciones personales que es lo mínimo necesario para vivir con autenticidad. Aunque estemos en un mundo apático no debemos dejarnos llevar, nuestra fe no puede ser una fe tan general que se 
convierta en una fe supuesta pero no vivida. Es absolutamente imprescindible cambiar nuestra fe muerta por una fe viva o no podremos ir a ninguna parte.

\section{Modernidad y postmodernidad}

Los enunciados de la modernidad, vgr. en la vida social, pueden resumirse así: a) es necesario un orden social y político para que triunfar tenga sentido. b) El triunfo es el resultado de la racionalización de nuestra conducta. Y c) en nuestro mundo triunfar significa: tener poder económico, poder social y poder político (Tierno Galván, E., Idealismo y pragmatismo en el s. XIX español).

La postmodernidad no deja en pie ninguno de estos enunciados. Hoy vemos el orden social no como un medio para triunfar sino para vivir. Se rechaza el orden porque está, con mucha frecuencia, siempre en función de unas personas concretas que intentan controlar hasta la providencia (Lyotard). Se rechaza la teoría del trabajo. No es verdad que triunfa el que más trabaja, los que más se entregan, ni mucho menos. Y ésta es ya una vieja tragedia del mundo y de la fe (libro de Job). Triunfar para un postmoderno tampoco significa tener poder, sino que triunfar hoy es : estar bien, vivir bien, sentirse bien. Ahora hay más gente que realmente se cree que triunfar es estar contento, en coherencia y tranquilidad, en paz consigo mismo. Y no con una idea general o metanarrativa que nos justifica en todo (Lyotard).

Así, hoy día, el individualismo no se identifica ya simplemente con el egoísmo. De hecho ha sido el cristianismo el que ha creado la idea de persona (Henry-Levy) humana y de personalización de la vida. El creyente no se contenta, solamente, con sentirse bien. Creemos en el sentido vocacional de la vida y en la esperanza de la misión y la fraternidad humana. Así el creyente al ser fiel a Dios es fiel a sí mismo y viceversa. No estamos haciendo cosas raras. La vocación es la dimensión más profunda de la entrega a una humanidad más humana (Vaticano II, Juan Pablo II, Dominum et vivificantem, 59). La oración es siempre la voz de los que no tienen voz (Ib. 65). Como hoy la fidelidad a sí mismo ha sido rota (S. Agustín, Ortega: el hombre huye de sí mismo y se chantajea a sí mismo), las vocaciones andan también por el mismo camino. El hombre actual está muy desorientado, huye de sí mismo, se tiene miedo, se encuentra ante una disolución de la cultura, de la familia, de la persona. Estamos ante una desubstancialización de la vida.

Es imprescindible enfrentarse a esta situación y no contentarse con sentirse bien. Buscar la propia expansión, únicamente, es caer en una falsa espontaneidad que lleva a mantener constantemente la propia comedia. Hay, pues, que recuperar profundamente el sentido de la propia vocación. A lo que vinimos... es necesario afrontar el vacío y la kenosis. Estamos ante un mundo con 
una gran desorientación y una gran indiferencia. El vacío ocurre cuando no se tiene nada porque se ha perdido todo. La kenosis y el anonadamiento proviene, en cambio, de que no se tiene nada porque se ha entregado todo, incluido a uno mismo. En el anonadamiento uno puede demostrarse a sí mismo que es capaz de acercarse, darse, de verdad, al otro gratuitamente, porque se prescinde realmente de uno mismo y sus propios intereses, a imitación de Cristo que se dio incondicionalmente por amor.

Es fundamentalmente a este cristianismo misionero, al que se ha sido infiel (P. Blanquart) ${ }^{6}$. Ésta es la fe cristiana que nos invita a perder nuestra vida por los demás para así ganarla en Cristo. Y así poder expresar la profundidad de la gratuidad y el don a los demás que escucha y da acogida de verdad al prójimo y sus sufrimientos, al grito de los pueblos condenados y oprimidos. Es así como cada cual debe morir un poco, o un mucho, a sí mismo y a su cultura para entrar en la cultura y en la vida de los demás (Finkielkraut). Fue primero Cristo mismo, y tras él, siguiendo sus huellas, san Pablo y los demás, quien abandonó su propia cultura - judaico-farisea - y se abrió a la cultura universal, al amor incondicional de la vida y de la humanidad que sufre en el camino. Esta mística de la misión es la que hace que la persona perciba claramente que a veces siente el dolor del calor del propio hogar abandonado, y en ese sentido, perdido. Esta herida, para que no sea profundamente infecunda $\mathrm{e}$ inútil, ha de transformar nuestra vida en entrega incondicional a Dios y a los demás.

Lipovetsky insiste incansablemente en la individualidad -personalidad - imprescindible hoy más que nunca. Para nosotros es la entrada en una fe más auténtica y verdadera, más personal y más humana, es también la creación de una convivencia más cordial donde se pueda realmente vivir de un modo más humano como personas realmente libres (nadie me quita la vida si no que yo la entrego libremente, Jn). De hecho la sociedad postmoderna no admite las presiones autoritarias, de ningún signo, ni acepta ya a los grandes ídolos o tabúes y tiende a una insularidad ontológica que ha de ser evangeliza-

6. Hoy el hombre exige: no violencia, antirracismo, aceptar las diferencias y un nuevo sujeto humano. Es a la formación de este nuevo sujeto a lo que el cristianismo puede contribuir con toda su profundidad: «La originalidad de Cristo es haber vivido vaciándose de sí mismo (Fil 2,7). La kenosis es ese acto en el que uno se prueba a sí mismo por la entrega al otro. A esto es a lo que el cristianismo misionero ha sido infiel cuando, en la época del individuo clásico (sobre todo en las Américas), él se ha identificado, sobre todo, con el conquistador (homogeneización occidental) más que con el descubridor del desconocido. BlanQuART, P., L. et V., 184 (1987) 80-81 «Nouvel individu et avenir du christianisme» (trad. nuestra). Es una fe que se da al prójimo hacia una cultura inédita e inefable, de una fraternidad sin fronteras frente al fariseísmo excluyente, es la herida mística de la hospitalidad del buen samaritano de la humanidad que es el misionero. $\mathrm{Y}$ no un hombre envuelto en el seno materno bajo el complejo de Joseph. 
da: lo que importa es la felicidad de cada uno, lo otro no importa. La comunidad no se salva si no se salvan las personas y viceversa.

Se ha criticado al individualismo en nombre del nacionalismo. También se ha criticado el totalitarismo en nombre del sentido de comunión en el cristianismo. Bueno sea todo, pero tengamos cuidado (Finkielkraut) ${ }^{7}$ de no crear nuevos ídolos.

Como ejemplo de actitud que el creyente debe tomar ante esta situación, tan especial y complicada, se propone a los hombres de empresa que hoy llamamos yuppies o nuevos empresarios jóvenes. Se trata de personalidades dinámicas, autónomas y con un sentido joven y nuevo de la vida que no están dependiendo, principalmente, como la mayoría, de los tradicionales miedos, generales, en el tinglado económico. Los creyentes actuales tenemos que situarnos en un estado - yuppie- emprendedor ${ }^{8}$ porque si no terminaremos como camellos que avanzan solos por el desierto bajo las pesadas cargas de las grandes normas, las solemnidades ideales, y nos pareceremos a vendedores de una droga ajena - la fe- que ni sabemos de dónde va ni a dónde viene, ni para qué sirve, ni a qué conduce. Necesitamos, por tanto, vivir activamente nuestra fe, con sentido evangelizador, militante y misionero, de lo contrario terminaremos por tener la sensación de que somos expendedores-repartidores, delegados de la central de la droga-opio del pueblo, que sería una religión anémica, antihumana y sin vida.

Esta situación nos exige una espiritualidad nueva que hemos de asumir personalmente en el cristianismo. Así el espíritu emprendedor no es un objeto de la comunidad sino que vive realmente aquello con lo que se ha comprometido, con una gran libertad personal pero también con una convicción y una eficacia real, en el sentido de que se trata de una fe que tiene una relación real y

7. Hemos de tener buen cuidado de no confundir a Dios con el espíritu nacional o el alma del pueblo (izquierda): «Teócratas, quieren salvar al mundo de un desastre fundamental - la disolución del derecho divino-, pero lo que denominan Dios ya no es el ser supremo, sino la razón colectiva. Identificada con la tradición, presente en el genio de cada pueblo, ese Dios ha abandonado la región celestial del bien soberano por los parajes oscuros y subterráneos del inconsciente» FINKIELKRAUT, La derrota, 21. Nadie tiene en exclusiva el alma nacional en toda su pureza (Vattimo).

8. Esta comparación es original de BERTHOUZOz, R., se trata de un hombre emprendedor, que mira la vida como una gran aventura en medio de la actual tristeza. Eso supone libertad personal, solidaridad, eficacia, en lo posible, y vivir la realidad personalmente: L. et V. 184 (1987) 91: «Implication éthiques des modèles actuels d'individualisme». Hoy se vuelve a valorar la plenitud personal, la responsabilidad propia irreductible, Ib., 85. Más comunidad y menos institución. Se pide fidelidad a fondo, ya no se puede ser creyente como por descuido: «En medio del gran número de bautizados que sólo son cristianos como por descuido, ante tantos hombres que han seguido siendo creyentes a lo largo de sus años de una manera tan poco adulta que, con la edad, resulta pueril, cabe preguntarse: ¿tienen unos y otros la misma religión?»: LEGAUT, M., Creer en la Iglesia del futuro. Sal Terrae, Santander 1988, 15. 
concreta con la vida. De lo contrario nos asaltarán constantemente las dudas y los problemas, sin descanso, dado que no creemos realmente en nada, ni tampoco en lo que hacemos.

Por otra parte, un cierto grado de solidaridad es siempre también necesario. El creyente nunca debe ser una isla perdida en el océano. El fin de la vida del hombre emprendedor debe ser siempre la comunidad: nadie evangeliza por sí y ante sí, la evangelización es siempre un acto eclesial (E.N. 60). El fin de nuestra vivencia es siempre una convivencia, somos en comunión; no hay fe sin Iglesia. Se trata, por tanto, de una nueva personalidad que lleva a una nueva comunidad. El peligro del yuppie - del hombre emprendedor- es caer en una excesiva singularidad, en el individualismo egoísta de querer realizarse uno solo. Por eso - hemos de llegar a acuerdos, aceptar que no podemos vivir simplemente a nuestro aire; responsabilidad es siempre corresponsabilidad y un compartir comunitario. En la vida oficial se necesitan también siempre acuerdos mínimos. Lo más importante es el Espíritu, por supuesto, pero un poco de orden también es necesario. Es menester que no nos falten las raíces, la historia y la organización, la tradición, aunque lo fundamental sea la fe, mi entrega a Dios y a los demás, siempre solidarios. Como nos dice san Agustín, todo buen solitario es solidario, y viceversa.

Además, aunque el yuppie no sea un proselitista, sí que cree realmente en lo que hace y por tanto le interesa realmente que otros compartan la misma vida y el mismo estilo. El cristiano necesita compartir su experiencia de fe y del reino (todo evangelizado, a su vez, evangeliza). Así propone a los demás su camino, su experiencia de la fe y de la vida y le invita a su vocación...

En el cristiano, la fe, además de comunitaria o eclesial, ha de ser siempre personal. Dios se dirige a mí y me da la felicidad. Es la dimensión individual; por tanto hay que insistir en la experiencia íntima de la fe que nos dará una personalidad propia, porque a cada cual le revela su vida, su vocación y así le confiere una identidad. Así la persona se hace más autónoma y auténtica. Es necesario hoy hacer que haya lo que no hay: amor, justicia, paz, pero sobre todo hacer que haya convicciones auténticas donde no las hay, ya que son imprescindibles. Es así como el creyente deviene cada vez más persona. Dios no es su competidor sino su liberador absoluto. Es él quien llama a plenitud, a ser cada uno él mismo una persona auténtica. Él me llama también a la entrega de mí mismo y a la entrega a los demás para que no me quede en el egoísmo, el narcisismo ni en el ombligismo solitario. 


\section{La apatía actual}

Se trata de un nuevo estilo de apatía. Se prescinde casi totalmente de las antiguas lamentaciones. En la apatía actual ya no hay dramatismo ${ }^{9}$. Casi nadie siente ya ni desesperación extrema ni experiencia inmediata del absurdo. Se trata de una indiferencia fría, alejada del nihilismo y de la vanidad universal. Por eso nada tiene que ver con el suicidio. Hoy no hay valor suficiente para afrontar la propia destrucción. Hasta ese punto llega la falta de coraje moral. Por eso, no es verdad que haya subido el número de suicidios. El hombre actual, ante el vacío de sentido, no se enfrenta a la angustia existencial o al pesimismo dramático. Se busca la compensación con mucha más indiferencia y no hay una ruptura total ante el desastre metafísico de la falta de sentido.

Hoy día falta la gran crispación del pasado, en general no hay una intensidad emocional fuerte, como tampoco hay un sentido fuerte de responsabilidad. Es una situación de desinflacción general, la persona no percibe presiones dramáticas sobre su vida. Tampoco las depresiones actuales son como las de antaño; son menos dramáticas aunque estén más generalizadas. Los entusiasmos también se han atemperado mucho. Es un entusiasmo frío, congelado, controlado y discreto. En el fondo se percibe un gran desencanto ante la vida y un desencantamiento del mundo. Ya no hay cosas dramáticas. Las relaciones humanas son duras, frías, normales (Handke, M. Duras) ${ }^{10}$. Ya no hay rebelión a gritos ni grandes revueltas, se percibe un sordo silencio... más que un odio declarado.

Así, en la situación social, no existe abierta lucha de clases ni antinomias irreconciliables de grupos; todo el mundo pacta, más o menos. Lo bueno y lo malo, lo falso y lo verdadero, el sentido y el sinsentido se han vuelto más débiles. Hay, por eso, mucha confusión. La vida se vive en secuencias de flashes ${ }^{11}$. La misma necesidad de sentido ha sido, en gran parte, barrida y la vida indiferente ante todo campea por sus fueros. Se puede vivir, puesto que de hecho se vive, sin patetismos ni dramatismo y sin escala de valores. Al parecer no se pretenden tampoco nuevos valores. Algunos incluso piensan que nos hemos liberado de unos sueños mortíferos que eran fantasmas de ideas asesinas, propias de los 'grandes sacerdotes del desierto'.

9. LiPovetSKY, La era del vacio, (en francés) 42 y ss.

10. «¿La violencia y el sinsentido no son, al fin y al cabo, una y la misma cosa? (M. Horkheimer)»: HANDKE, P., El momento de la sensación verdadera. Alfaguara, Madrid 1981, 10. Ib. 43: «En fin, nada tenía sentido, solo una apariencia de ingeniosidad; demasiada, pensó Keuschnin». Ib., «Todo estaba ensayado y nada les podía suceder, porque de entrada todo tenía un orden». Ib. 121: «Keuschnig se acercó a la mesa de piedra y leyó la nota que había escrito Stefanie. «No esperes que yo te facilite el sentido de tu vida». Se me ha adelantado, pensó humillado».

11. BAUdRILlARD, J., Las estrategias fatales. Anagrama, Barcelona 1984, 179 y ss. 
En resumen: la indiferencia crece, el prestigio de la enseñanza, el prestigio de los enseñantes tiende a desaparecer, el discurso magisterial se ha desacralizado, hay una gran desafección hacia el saber, hacia las clases, hacia los maestros ${ }^{12}$, el colegio, el cuartel y el desierto funcionan igual: en ellos las personas ejercen la ley del mínimo esfuerzo y el mínimo interés con toda evidencia. El compromiso social cae cada vez más desde mayo del 68. No es cierto que la irreligiosidad sea cada día creciente, también en esto la apatía impera y manda; la apatía política aumenta, en gran parte debido a la enorme cantidad de información que continuamente recibimos y que no podemos procesar, hay una gran desafección hacia el trabajo y el esfuerzo: la enfermedad, para librarse del trabajo, cada día abunda más. También la gente se resiste, cada vez más, a que le cambien de trabajo.

Hay una vuelta decidida a la casa paterna, a lo particular, a lo regional, a los pueblos, pero esto no indica un nuevo interés sino también indiferencia ante: la idea del progreso, el valor de la ciudad, de la velocidad, y de la revolución. Además el futuro ya no entusiasma a nadie. Todo está en la UVI ${ }^{13}$.

La indiferencia conduce a que todos los comportamientos se mezclen, todo es ambiguo. La fe actual es una fe fragmentada, y lo mismo la vida. La fe cada vez se centra más en la apoteosis de la propia vida. Pero la persona cada vez está más desestabilizada.

La apatía afecta por igual a las personas educadas y bien informadas y a las que no lo están. Teniendo en cuenta que la apatía no es contentarse con lo que hay, sino que todos ensalzamos y nos entusiasmamos con muchas cosas, pero transitoriamente, la vida no da más de sí.

La indiferencia se fortalece aún más por la falta de acción. La persona se cierra en sí misma. Y no cree ya para nada en las instituciones, se tiende al aislamiento dulce y blando. Cuando las cosas son así, los ideales y valores oficiales se marchitan y caen sin parar. En las congregaciones religiosas esto se nota como desafección ante lo congregacional, el sentido de Provincia ${ }^{14}$ no se ve. Así, sólo resta la búsqueda del yo y del interés propio, es el éxtasis por la liberación y la realización personal. La obsesión por el propio cuerpo. Hay una sobre-inversión en los temas de lo privado y mucha abstención ante la comunidad y lo social. Lo que interesa sobre todo es la comodidad y el vivir bien. A eso se le puede llamar humanización de la vida religiosa... Los únicos valores fuertes aún son la comunicación y el psicologismo. Esto lleva a una deserción

12. Lipovetsky, La era del vacio, (en francés) 44. Cfr. también Agnes Heller.

13. Puig, A., Pre-moderns, transmoders I postmoderns, Papers. Revista de sociología, n. ${ }^{\circ}$ 25. Universidad de Barcelona, 1985, 32.

14. Las quejas sobre esta cuestión son constantes, cfr. Carta del Consejo Provincial de la Prov. de Filipinas en 1987. Idem. Proyecto de pastoral juvenil, 3,21 y ss. 
de la comunidad y al encierro en grupos emocionales. Entonces la persona camina hacia el desierto final.

Así lo último y lo primero es la deserción de sí mismo. Cuando la deserción social llega a la esfera privada y no se respeta nada, no quiere decir que se termina en el suicidio. De hecho en París de 500 suicidios por un millón de habitantes en 1970, se bajó a 100 suicidios por la misma población en $1987^{15}$. El suicidio es incompatible con la era de la indiferencia que no admite posturas extremas ni ante la vida ni ante la muerte. Por el contrario, el amor del desierto y la desesperación relativa de la indiferencia conduce a una patología de masas que se resuelve simplemente en el andar flipao con el propio problema, el desinterés y la indiferencia. El hombre de hoy se instala de una forma indistinta entre la exaltación y la depresión. No es que actualmente haya menos enfermedades psicológicas ni más que antes. Lo que ocurre es que están más generalizadas y así son más comunes. Antes la depresión era propia, sobre todo, de las clases acomodadas, hoy día casi nadie escapa, más o menos, a ella.

La desertización social lleva a una democratización sin precedentes del mal de la vida que es hoy una plaga difusa y endémica. El hombre actual no es tampoco más sólido que la personalidad puritana y disciplinada, como a veces se cree, pero tampoco le importa. $Y$ cuando hay inseguridad no se pueden buscar soluciones donde no las hay, por ejemplo, recurriendo a la fuerza. La indiferencia generalizada ha llegado a la vida misma. Hoy día el hombre se caracteriza por la vulnerabilidad, y la inestabilidad hay que afrontarla tanto en la sociedad, como en la Iglesia, como en sí mismo. No se puede encomendar a un cuerpo de guardia. Somos personas débiles y nos encontramos expuestas a muchos riesgos.

La generalización de la depresión revela las dificultades del mundo actual. La persona individualista se hace susceptible en cualquier dificultad y se encuentra sin fuerza y desprotegida ente ella. Hoy día todo está sujeto a stress, a presión, a temor. Siempre podemos fallar, al envejecer, al engordar, al dormir, al vivir, al morir, al amar. Y así actividades elementales pueden volverse casi imposibles para la persona. Y eso le lleva a pedir: dejadme solo, dejadme en paz; es la indiferencia general, algo puramente inercial (Handke) ${ }^{16}$. Había

15. LIPOVETSKY, La era del vacío, (en francés), 52.

16. Se vive de memoria, de memoria se simula la vida, como los seriales, «icomo si fueran la vida misma! (pero ¿en qué país o en qué sistema no se contaban simples seriales como si fueran vivencias propias?»). HANDKE, El momento, 56. Ib. 86: “QQué maravillosamente sólo me siento!». Ib., 98-99: «Sólo soy solidario con la que gente que no encuentra sentido en sus actividades. Y precisamente en el último tiempo he encontrado muchos tipos así y los he ratificado en su actitud». Ib. 101: «'creo que no quieres saber nada de nadie, porque lo especial, pero poco llamativo, que tú enseguida quieres descubrir en todo, se ha agotado. Ahora habría que descubrir lo inagotable, lo cotidiano, que tú pasas por alto asqueado'». Es así como hoy vivimos en el exilio, 
que volver a las cosas mismas. Hay que proponer una mística de la cotidianidad, de la asunción de la propia historia y vida personal.

Según Lipovetsky la deserción social y la indiferencia actual concuerdan perfectamente con la lógica fundamental del capitalismo. La indiferencia permite que el capital funcione libremente sin trabas religiosas, morales o políticas. La gente se deja mover por el panorama de la trama social. Se da una indiferencia por saturación de información y experimentación. Se realizan toda clase de experimentos y se toman las más variadas posiciones. Realmente pudiera decirse que la sociedad actual carece totalmente de las mínimas convicciones y valores ${ }^{17}$. Por eso también, la retórica de la información ha perdido valor y la indiferencia es cada vez mayor, de modo que nos encontramos ante una profunda anemia emocional. El desierto está ante nosotros: todo se vuelve más frío. Y esto nos obliga a una nueva conquista de la soledad y del silencio. La revolución también se ha vuelto más fría y menos emotiva. Así, para Lipovetsky, mayo del 68 es una revolución en frío, enormemente cívica, un movimiento laxista y sin presión.

Hoy contemplamos una deserción general de los valores tradicionales en la sociedad. Después del vacío existencial y del desierto de la indiferencia, la deserción de los 80 no tiene principio ni fin. Todo lo que antes parecía valer parece que ahora no vale. Por otra parte tampoco sirven los guardias. Cada cual tiene que vivir sus propias convicciones y no puede vivir de lo que viven los otros. Cada uno tiene que ser realmente el guardián de sí mismo y de sus propias convicciones así como de su propia fe. Pero, con frecuencia, la persona se atomiza, se atrinchera y dice: dejadme solo. Frenta a esto hay que reaccionar recuperando el valor de la comunidad y la convivencia.

de nosotros mismos, de nuestra tradición, de nuestras instituciones: fin de las ideologías, de las creencias, hemos perdido la memoria, la ilusión, sólo las cosas de cada día nos recupera la memoria si aceptamos perdernos en la realidad en vez de tratar de dirigirla y conquistarla: 'El que pierda su vida la salvará', es una nueva mirada sobre el mundo tras la reconciliación con la realidad y la pacificación: BELLAY, J.Y., L. et Vie, 184 (1987) 49.

17. LipovetsKy, G., La era del vacio, 162: «Bajo el empuje de los valores hedonistas y narcisistas las referencias eminentes se vacían de substancia, los valores que estructuraban el mundo en la primera mitad del siglo XX (ahorro, castidad, conciencia profesional, sacrificio, esfuerzo, puntualidad, autoridad) ya no inspiran respeto, invitan más a la sonrisa que a la veneración: parecen fantasmas de vovedil, y sus nombres evocan a nuestro pesar algo vetusto y ridículo»... es «la desubstancialización humorística de los principales criterios sociales». Hay según Vattimo una disolución de los valores cuyo símbolo es la muerte de Dios, todo es negociable y negocio, la liturgia deviene metalurgia: VATTiMo, G. El fin de la modernidad, B. 1986, 26. 


\subsection{El narcisismo del mundo actual}

Los sociólogos han estudiado el narcisismo de la juventud radical actual con cierto detenimiento ${ }^{18}$. Narciso se ahoga a sí mismo, en su propia fuente. El narcisismo es, para Lasch, el tema central de la cultura actual. Es la cultura de los años 80 donde el hombre realiza un profundo cambio antropológico que podemos llamar neonarcisismo. No es el Edipo de antaño, tampoco el Fausto moderno, se trata de un perfil inédito del hombre que indica las nuevas relaciones que mantiene consigo mismo, con los otros, con su propio cuerpo y con su mundo. Este cambio es simultáneo al paso del paleo-capitalismo autoritario al neocapitalismo consumista: hay que consumir a toda marcha para que las fábricas sigan marchando. Es el individualismo económico donde la familia, el arte, la religión están desapareciendo y naufragando junto con la creencia en el futuro y el progreso. El neonarcisismo es la indiferencia histórica pura. La última fase de la postmodernidad. El hombre es igual que todo y todo da igual.

Después de la agitación social y política de los años 60 y 70 nos encontramos ante una gran indiferencia a las cuestiones sociales. Hay un reflujo de las compensaciones hacia lo puramente individual. Por eso ahora es imposible ningún tipo de compromiso, incluido el religioso, sin una profunda experiencia personal. Positivamente se da una despolitización de la religión (se van los que hacían política de todo, aunque se han quedado los vencedores que pronto serán los nuevos rebeldes); pero eso tiene un gran peligro desmovilizador y de indiferencia a todo. Para Lipovetsky, quedan ya muy pocas causas capaces de arrastrar realmente a la gente ${ }^{19}$. La cosa pública ha perdido interés - se mantiene algo en la cuestión militar por los verdes y por el miedo general-. Todas las cuestiones referidas a los grandes problemas, a las grandes cuestiones, se han hundido: hay una operación general de neutralización y banalización de las cuestiones graves. Solamente la esfera privada ha salido victoriosa de la batalla. Sólo las experiencias psicológicas suscitan aún interés. Lo que importa ahora es vivir el presente, nada nos dice ya el pasado y menos el futu1979.

18. De Miguel, A., Los narcisos. El radicalismo cultural de los jóvenes. Kairós, Barcelona

19. Esta afirmación no puede tomarse como algo absoluto. Tampoco se puede decir, sin más, los jóvenes son así o así. Es lo que ocurre a un estudiante del 1986: «Desde que existo, yo oigo decir: 'los jóvenes son individualistas; no tienen corazón, lo único que quieren es tener éxito'. Yo quiero triunfar, cierto, pero también tengo un corazón y pienso en los demás... Yo creía que era el único caso, que todos los otros, como se decía, eran individualistas, cínicos, de derechas y todo eso. Yo me he ido a la manifestación para ver si había allí otros como yo. Ellos han bajado para ver si estarían solos en la calle. Pero han descubierto que allí estaban todos. Que se les había engañado sobre ellos mismos. Esto es lo que ha pasado" (Le Nouvel Observateur, 5-11XII-1986): SIMON, M., L. et V., 184 (1987) 6 (trad. nuestra). 
ro. Se ha perdido el sentido de la historia. Así se refleja en la erosión del sentido y el sentimiento de pertenencia, vgr. eclesial, congregacional, provincial. Es necesario reaccionar ante esto, no basta con tapar. La sucesión generacional y sus tareas han sufrido un duro golpe a causa del mundo y la cultura narcisista. El sentido histórico ha entrado también en el desierto de la indiferencia. Esto es tanto más grave cuanto, como se ha dicho muy bien, quien no tiene pasado no tiene futuro.

Del mismo modo, con la pérdida del sentido histórico ${ }^{20}$ la crisis de confianza hacia los líderes y hombres ejemplares se ha precipitado. Así surgen graves problemas de identidad personal, de confianza en la comunidad y en la misión. Hay también una crisis de confianza en la Iglesia y la reanimación de la fe, y las convicciones profundas de las personas también se han visto afectadas. Del mismo modo la misión sufre las consecuencias, pues cuando el futuro aparece incierto nos replegamos fácilmente hacia el presente. Pero así entra también en crisis el sentido colectivo del proyecto común, del cambio necesario y de todos los mesianismos, verdaderos o falsos. De este modo ha caído también la idea del progreso que ahora se reduce, como decía L. Mumford, a la buena imagen que de sí misma tiene la clase dominante. Por lo cual se produce una desmoralización general del sentido social y del futuro común.

20. En la polémica Sartre-Levy-Strauss se vio hasta qué punto la objetividad de la historia consiste en que no tiene objetividad alguna. Así la historia «es una manifestación de la cultura de los dominadores»... «En consecuencia, ésta (la revolución) pretende llevar a término una especie de redención que haga justicia, es decir, que vuelva a dar la palabra a todo aquello que ha sido excluido y olvidado en la historia lineal de los vencedores»: VATtimo, G., RovatTi, P.A., (eds.), El pensamiento débil. Cátedra, Madrid 1988, 23. Por eso: «La disolución de la historia, en los varios sentidos que pueden atribuirse a esta expresión es probablemente, por lo demás, el carácter que con mayor claridad distingue a la historia contemporánea de la historia imoderna!: VATTIMO, G., El fin de la modernidad. B. 1986,17. La disolución de la historia es la disolución de la fe en el progreso y en el futuro mesiánico: «La historia que, en la visión cristiana de la cultura aparecía como historia de la salvación, se convirtió primero en la busca de una condición de perfección intraterrena y luego, poco a poco, en la historia del progreso: pero el ideal del progreso es algo vacío y su valor final es el de realizar condiciones en que siempre sea posible un nuevo progreso. $Y$ el progreso, privado del 'hacia dónde' en la secularización, llega a ser también la disolución del concepto mismo de progreso, que es lo que ocurre precisamente en la cultura entre el siglo XIX y el siglo XX: Ib. 15. Entonces, todo cambia, la historia ya no es lo triunfante, sino lo que sucede: «El verdadero trascendental, lo que hace posible cualquier experiencia del mundo es la caducidad; el ser no es, sino que su-cede, quizás también en el sentido de que cae junto a, de que acompaña -como caducidad-a cualquiera de nuestras representaciones». VATTIMO, G.-RovATTI, P.A., El pensamiento débil, 34. Esto nos lleva a no ocuparnos solamente de los fuertes y los dominadores sino también de los débiles y marginados: «La piedad por estos despojos representa el único verdadero motivo de la revolución, más que cualquier proyecto presuntamente legitimado en nombre del derecho natural o del curso necesario de la historia» (Ib. 41). Solamente así es posible reconquistar el sentido de la historia: «Uno vuelve a apropiarse del sentido de la historia con la condición de aceptar que ésta no tiene un sentido de peso ni una perentoriedad metafísica y teológica. VATTIMO, G., El fin de la modernidad, 31. 
La inmoralidad, más llamativa, ahora vigente, no es más que una forma de venganza por el sinsentido de la vida en el que nos encontramos atrapados, como en una gran trampa. Se cae así en una apatía frívola, en donde todo es catastrófico, en donde todo es crisis pero nada importa: moral económica, social, política; todo da igual. Nos instalamos en la crisis, el que puede, pero en la crisis nos replegamos desencantados sobre nosotros mismos y esto nos lleva al egoísmo pacífico pero profundo. Se da una profunda indiferencia y desafección a los grandes sistemas y grupos de sentido: partidos, iglesias, valores universales ${ }^{21}$.

Entonces se puede caer en la trampa de vaciarse de sentido social y caer en el cultivo del individualismo puro y duro. Se llega así a un aislamiento a la

21. Cfr. nota 13. Los que parecen valores y verdades muchas veces son estratagemas del poder: «La fuerza del pensamiento ya no tiene nada que ver con su presunta relación con los fundamentos últimos, como tampoco la forma que reviste semejante poder es la de un explícito principio de autoridad. Más bien debemos buscarla en la normalidad cotidiana. El sacerdote y el tirano, aunque sigan existiendo materialmente, no tienen hoy función alguna que desempeñar. El panorama ha perdido altura»: VATTimo, G.-RovatTi, P.A., El pensamiento débil, 65. De este modo el ideal parece vacío como el bien: «En otro tiempo, el conservador burgués encarnaba lo universal, su bien era el Bien - como afirma Simone de Beauvoir en 1955-, pero 'la expresión: ideología burguesa, hoy no designa ya nada positivo', ya no hay esperanza, uno alimenta sus miedos, 'la burguesía continúa existiendo: pero su pensamiento catastrófico y vacío no es más que un contrapensamiento'. ¿Vacío? Queremos decir vacío de un Ideal absoluto, privado del Bien Supremo»: Gluksmann, A., La estupidez. Ideologías del postmodernismo, Península, Barcelona 1988, 111. Así hemos perdido los fundamentos que nos sostenían, al menos aparentemente: «La situación es aquella en la que nos encontramos viviendo, caracterizada por la ausencia de puntos estables, por la fragmentación de nuestro horizonte histórico y natural. Inciertos no son sólo los valores según los cuales hemos habitado históricamente la tierra, incierto no es sólo el concepto 'histórico' en cuanto factor de historia, del valor; incierta, insegura ha llegado a ser la tierra misma»: VITIELLO, V., Expresar la contradicción, ER, 5(1987)125. Vivimos en un mundo fragmentado, aunque la situación quizá no sea tan dramática sino que hemos de verla como un nuevo kairós, una nueva presencia de Dios hoy. De hecho T.W. Adorno nos habla del pensamiento actual como una resistencia a lo que simplemente es y «afirma que el conocimiento tiene como función 'establecer perspectivas en las que el mundo se desequilibre, se enajene, saque a la luz sus fracturas y sus grietas, y se deje ver deformado y débil, tal como aparecerá un día bajo la luz mesiánica». (Minima Moralia, Turin, Eiunadi, 1954, 234). CRESPI, F., Ausencia del fundamento y proyecto social, en VATTIMo, G.-RovatTi, P.A., El pensamiento débil, 354. Tal es hoy nuestro destino frente al triunfalismo de la razón y de la historia: «La falta de absolutización que, contradistingue tanto a la afirmación del carácter radicalmente acotado del pensamiento cuanto a la de la imposibilidad de concordia existencial, es lo que constituye la connotación débil de un pensamiento contrapuesto, por naturaleza, a todo triunfalismo lógico o historicista» (CRESPI, F., ib. 246). Y esto es y tiene que ser así porque: «El tomar críticamente conciencia de la fuerza destructora inscrita en la ratio, en la relación ratio-dominio, no es la consecuencia de un auténtico debilitamiento de la estructura de poder, sino que surge en el momento en que, por haber alcanzado ese sistema su máximo grado de objetivación, entran en crisis las formas ideológicas que lo legitimaban», J.F. LYOTARD, La condition postmoderne, (Paris, Minuit, 1979; CRESPI, F., ib., 349). O dicho de otro modo: "La conciencia de los límites del saber se contrapone, efectivamente, a la experiencia fuerte del pensamiento, caracterizada por la posesión de la verdad y del fundamento absoluto, y destruye radicalmente las bases que legitiman el poder y la norma»: (CRESPI, F., Ib., 342). 
carta, psicologización cada vez mayor, privatización sistemática de todo e individualismo absoluto.

Y sin embargo, el individualismo, bien entendido, puede tener un cierto sentido positivo. El individualismo procedería, en gran parte, de que la persona no es capaz de amarse realmente a sí misma. De hecho, todo lo más individual tiene una referencia social y todo lo más social tiene una referencia individual. Pero el individualismo conduce fácilmente a una dulce somnolencia, aunque supondría siempre un apasionamiento más o menos grave por la propia realización y el descubrimiento de una sensibilidad propia. Pero a veces la persona no sólo comienza a interesarse por sí misma sino que da vueltas sin parar sobre sí misma. Esto es lo que conocemos por ombligismo ${ }^{22}$. Es la actitud de quien solamente le interesan, única y exclusivamente, sus problemas; se cree el ombligo del mundo y se crea una importancia exorbitante. Se trata de una tendencia a afirmarse sin los otros o contra los otros. El individualista no sueña a los demás. Es cierto que la caridad bien entendida comienza por uno mismo, pero no es menos cierto que no acaba en uno mismo. La realidad corporal nos recuerda que procedemos de otros, nadie viene de sí mismo. El individualismo actual se apoya en una exacerbación del yo para fundar una vida sin los otros.

En todo ser humano hay siempre como un principio de insuficiencia. En el individualista solamente hay autosuficiencia. Él cree bastarse totalmente a sí mismo. La meta del individualista es: amarse de tal manera a sí mismo de modo que no necesite de los otros para ser feliz (Rubin) ${ }^{23}$

En cuanto al psicologismo actual, hay que decir también que encierra un cierto sentido positivo: intenta pasar de la inconsciencia a la conciencia. Donde hay ello que haya yo, es ir asumiendo la propia vida, los propios miedos y encontrarse realmente consigo mismo. La persona asume el trabajo de la interpretación de la propia vida. Y la asimilación de su proceso de personalización. Eso nos debe llevar a liberarnos de los mecanismos de defensa y de nuestras construcciones enmascaradas. La persona ya no vive solamente de la experiencia ajena sino que trata de interiorizar personalmente su fe.

22. LiPovetsky, G., La era del vacio, (en francés) 60 y ss. El ombliguista se cree el ombligo del mundo; se toma por absoluto, no cuenta con el otro ni se plantea al prójimo; es «la bullenarcissique, le culte de l'individu, la contemplation du nombril, autant d'expressions qui recouvrent une réalité paradoxale, éminenment». CleRgET, J., L'individualisme et le sujet, L. et V. 184 (1987) 32. Se olvida que la placenta nos avisa de que no venimos de nosotros mismos; así en el cristianismo la oración no puede ser adoración ni culto de sí mismo. Es necesario aceptar que el hombre está condenado a sí mismo y a reapropiarse su vida sin caer ni en «el ombliguismo ni en la locura» (A. BELLAY, J-Y., La condition de l'individu moderne. Un parcour dans l'ouvre de Peter Handke», L. et $V$. ib., 38.

23. LiPOVETSKY, Ib., (en francés) 61. 
Pero la personalidad narcisista se centra de tal manera en lo suyo que su desafección hacia lo social es cada vez más fuerte. Al hacer de su vida el objeto exclusivo de su dedicación, el narcisismo reconcentra la persona sobre sí misma y así el desierto social es cada vez mayor, crea una extraña humanización rompiendo sus relaciones con los demás de modo que puede llegar a una glorificación de sí mismo.

Se nos ha dicho que somos imagen y semejanza de Dios, pero según Darwin y Freud, el hombre ni es dueño de su vida ni lo es de su propia historia. Y esto lleva a un vacío de identidad por una superconcentración en el yo. La vida queda desubstancializada, carece de sustancia y fundamento, de ahí que el relativismo es su lógica más inmediata. Como ya vimos, el esfuerzo tampoco está hoy de moda, la disciplina queda desvalorizada en beneficio de conseguir el gozo inmediato ante todo; se ha perdido la jerarquía de valores que es fundamental para una voluntad fuerte y decidida. Sin esa jerarquía nos atamos a la espontaneidad elemental, las asociaciones libres, el bienestar y, de esta forma llegamos a una conciencia fría y desenvuelta, indiferente a las grandes empresas de la humanidad que así parecen no tener sentido alguno. Es la era de la voluntad y del compromiso que desaparece. Se llega así a la desmovilización total de las masas y el yo del individuo, próximo a explotar, se mantiene en la indiferencia del escepticismo. Solamente resta el mundo puramente sentimental. Las decisiones que necesitan ideas y voluntad se hacen cada vez más difíciles. Así las personas no tienen vida propia y son dirigidas, desde fuera, por los elementos.

Necesitamos, cada vez más, una auténtica vida interior, vivida desde dentro, desde sí mismo. El ideal agustiniano de la interioridad en nuestra vida. $Y$ aunque es cierto que el culto a la interioridad pueda provenir de una personalidad que no es firme y busca un refugio, también es el lugar del florecimiento de la propia personalidad sin mirar tanto a lo que diga el mundo. Cuando esto se consigue, la persona se hace más flexible, acepta más fácilmente la formación permanente humana y espiritual, la propia reforma permanente. Las fijaciones obsesivas se destruyen poco a poco. El reino de la igualdad se extiende cada vez más sin que nadie pierda la individualidad. Pero cuando todos tenemos realmente una personalidad, la igualdad supone superar la inseguridad adicional que los demás nos crean. En cualquier caso, no puede haber futuro auténtico sin la conquista de la propia identidad y convicciones profundas.

En cuanto al cuerpo humano y el narcisismo actual, hay que observar lo siguiente: Hoy tenemos un cuidado generalmente excesivo del cuerpo que se ha convertido en objeto de culto. Este culto al cuerpo se nota en la angustia de la edad y de las arrugas, la obsesión por la salud, por la línea, la higiene, los cultos solares y las terapéuticas corporales. El cuerpo ha sufrido un profundo 
cambio en la estima social. Ha perdido estatuto de alteridad y de relación. Es cierto que nuestro cuerpo designa nuestra identidad profunda, pero sin serla, y ciertamente no es nuestra definitiva personalidad.

El cuerpo, al convertirse en el centro de la vida, se convierte también en espectáculo. El cuerpo es algo digno de respeto pero cuando todo se corporaliza encontramos que hay demasiada carne, según decía Ortega. El miedo actual, tan exagerado, a envejecer y a morir es un constitutivo del neonarcisismo. Lo mismo hay que decir de la degradación de las personas ancianas. Cada vez se ha ido perdiendo más el sentido del cuerpo. Así hemos caído en la autoseducción ${ }^{24}$. En este mundo de la obsesión por el cuerpo, la persona afronta la vida sin sentido transcendente. La personalización del cuerpo, por el contrario, debe ser un imperativo fundamental del futuro. El cuerpo tiene un ciclo vital. Hay que recuperar la idea del cuerpo como sujeto y no sólo como objeto. No obstante es muy importante cuidar del propio cuerpo. El cuerpo nos señala el inconsciente. El culto a la personalidad tiene mucho que ver con los imperativos sociales de ser uno mismo y guardar la línea. El cuerpo se vive también como una exaltación de sí mismo; esto hace que la persona se sienta mejor, más a gusto consigo misma. También, a veces, se da una desubstancialización del cuerpo y del yo: la persona no se encuentra a sí misma.

Lo que se dice del cuerpo se puede aplicar al vestido. La moda tiene también una antropología que revela una concepción social de la persona y del mundo. Se ha roto bastante, en esto como en todo, con los roles sociales y públicos tradicionales. Hoy se acepta que las cosas se fabriquen en serie: todos somos iguales, pero tiene que tener algo personal, pues cada uno es cada uno. A veces parece que el narcisismo nos llevaría a un grado cero de lo social, pero sabemos que no es así. Cuando hay un hundimiento excesivo de la vivencia social se produce paralelamente una gran melancolía de lo social e individual. En realidad todas las cosas, aún las más individuales, son a la vez sociales, y viceversa. Así los políticos al preocuparse por los demás se preocupan por ellos mismos, y lo mismo es cierto al revés.

\section{Otros aspectos de esta sociedad}

Aunque hoy parezca todo más descarado, hay sin embargo un sentido más frío de la realidad, no son bien vistas las emociones fuertes. Se confía poco en ellas. La autenticidad ha de ser siempre modesta y contenida. De ahí se sigue que tampoco se cree realmente en las grandes emociones, abiertas y fuertes. Hoy día se pide en todo un poco de discreción, de máscara, sobre todo en

24. Lipovetsky, G., Ib., (en francés), 69, 68 y ss. 
los momentos más duros de la vida. Así ocurre ante la muerte, y también frente a los conflictos de la comunidad donde puede ocurrir que unas personas luchan abiertamente o silenciosamente contra otras pero cuando el grupo sale al exterior se pide que se congele la situación.

La discreción en el discernimiento exige entusiasmo y frialdad. Las emociones excesivas no se admiten demasiado bien, se ven como algo inmaduro. Se pide a la persona que tenga un cierto control. El neonarcisismo pide que la persona se encierre en sí misma discretamente, en los momentos más duros, lo que implica que se domine a sí misma. Las emociones fuertes llevan a demasiados antagonismos. De ahí cierta indiferencia y caída de la militancia religiosa de las grandes ortodoxias. Una cierta desubstancialización de las doctrinas y de los proyectos lleva a una menor crispación de la convivencia ${ }^{25}$. De hecho cuanto más íntimas son las relaciones, más dolorosas son también: en la fraternidad, odio fraterno...

Actualmente se considera más razonable lo convencional, lo discreto, lo apático y civilizado. Se trata de desdramatizar cada vez más los conflictos. ¿Qué va a pasar? Lasch dice que hemos pasado de una lucha de clases general a una guerra de todos contra todos. Pero quizá lo bueno de esto es que esta guerra es algo relativa, pues detrás de ella cada persona tiene su vida en otra parte y no es fácil destruirla. Las discusiones se refieren a un frente de relativa

25. Se trata de una persona pacificada y sin gritos: LIPOVETSKY, G., Ib. (en francés) 74; que busca la igualdad sin perder el sentido democrático: Ib., 60. Y no insiste tanto en las doctrinas como en la convivencia igual, libre y fraterna para no dar lugar al poder de la fuerza: «La violencia de la teología, de la metafísica, del racionalismo y de la ciencia impregna, de principio a fin, toda nuestra historia, manifestándose como pensamiento fuerte de sus dogmas, de sus fundamentos ontológicos, de sus criterios 'objetivos'; y este descomedimiento horroriza a una razón que rechaza la posibilidad de imponerse a la realidad, y que tiende a entablar con ella una relación hermenéutica más cauta, inspirada por la atención, y a captar la interacción de dimensiones complejas, no reductibles a los esquemas unívocos de la racionalidad de la eficiencia. Un pensamiento en suma que avanza a través de ensayos y errores, reflexionando sobre las consecuencias que él mismo puede desencadenar; un modo de pensar que tiende a considerar errónea la certeza, y enganosa la seguridad de haber comprendido (J. Lacan 1955), Le séminaire I. III Les psychoses. Paris, Seuil 1981,67)»: CRESPI, F., Ausencia de fundamento y proyecto social, en VATTIMO, G.-RovatTI, P.A., El pensamiento débil, 349. Ésta es en el fondo la razón por la que en religión como en ciencia: «Los actuales no son ya tiempos de principios superiores, de fines últimos, de verdades definitivas»: Rovattı, P.A., Transformaciones a lo largo de la experiencia, en VATTIMO, G.-RovatTi, P.A., El pensamiento débil, 65. En definitiva, la fuerza no tiene razón, ni siquiera la fuerza de la verdad pura y dura, no se puede creer a cristazos ni trasformar la sociedad con los palos de la cruz, eso sería romper la ignominia de la cruz, entonces la debilidad humana ya no puede ser acogida, la sociedad impone su fuerza bruta; pero el futuro es de la responsabilidad: «el senti$d o$ del uso terrenal de la fuerza (ya en guerra, ya en política) no tiene fundamentos racionales, mientras que el ejercicio de la fuerza debe tenerlos, si se quiere que sus consecuencias sean limitadas. El hombre no tiene ningún poder, y sin embargo, tiene una responsabilidad. El porvenir corresponde a la responsabilidad; el pasado, a la impotencia»: DAL LAGO, A., La ética de la debilidad. Simone Weil y el nihilismo», en VATtimo, G.-RovatTı, P.A., El pensamiento débil, 141. 
importancia vital. No todo está tan mal y podemos reaccionar ante las situaciones, y cambiarlas. Lo mismo pasa con la riqueza, hay mucha gente que vive bien pero siempre se queja... Cada cual se esfuerza por avanzar en todos los frentes, desea ser más envidiado, más respetado. Nuestra sociedad se presenta como un sistema de rivalidad (Girard), concurrencia y competencia de todos contra todos ${ }^{26}$. Es necesario crear una moral del apoyo mutuo contra la noética de la rivalidad y la competencia. De lo contrario ocurrirá que la guerra y la lucha estará continuamente a nuestras puertas. Así, frente a la dominación del hombre el feminismo desencadena una agresión femenina que lleva al hombre a una respuesta más dura y a una agresión mayor. Para algunos también la rivalidad sería relativa y, en cierto modo, insustancial.

En resumen: la gente acepta hoy la democracia como algo normal. La rivalidad se refiere a cuestiones relativamente importantes. Nos peleamos por cualquier cosa. Hay un culto a las relaciones personales que se intentan mejorar. Se nota una disolución de las distancias sociales. Hay un crecimiento democrático de la persona. Se desea, por encima de todo, la igualdad.

Finalmente también hemos de reconconocer que hay un gran apetito de celebridad, es el instinto de prestigio ${ }^{27}$. El super-yo, a nivel de ideales, es fuertemente arrastrado por el deseo de ser estimado. También ha aumentado el cuidado positivo de la propia vida y sin embargo nos encontramos con una mayor inseguridad con respecto a la salud y a los ideales sociales. Hay una quema constante de estrellas y también de ciencia y conocimientos. La fe en la ciencia ha decaído. El nivel de convicciones es también hoy bastante bajo: se produce una desubstancialización de los ideales, hay anemia de realidad, y de ambiente vital. La nueva situación del mundo, en vez de llenarnos de nosotros mismos o del sentimiento de seguridad, nos llena de vacío. Hay una flotación narcisista en la realidad que ha sustituido a la crispación.

En cuanto a la persona, confirmamos lo siguiente: Se da una mayor insensibilidad a los demás y a la realidad, es un vacío emotivo por la anemia emocional. La desubstancialización de la realidad revela el proceso narcisista como una experiencia de vacío ${ }^{28}$. Estamos en el final de la cultura sentimental que creía en que las cosas terminan siempre necesariamente bien. El aumento

26. LiPOVETSKY, G., o.c. (en francés), 76.

27. El antropólogo culturalista afirma decididamente que el 'instinto de prestigio' es el más fuerte en el hombre actual sin comparación. En cuanto al valor del cristianismo, sentencia: «Es bien cierto que la conciencia cristiana debía haber cambiado el mundo, pero fue más bien el mundo el que cambió la conciencia cristiana».

28. Lipovetsky, G., o.c. (en francés), 85: «Incapaz de sentir el vacío emotivo, la desubstancialización llega aquí a su término, y revela la verdad del proceso narcisista, como una estrategia de vacío». 
de la envidia y el sentido de posesividad nos revelan quienes somos. Por todas partes encontramos soledad, vacío, insensibilidad, al avanzar en nuestra experiencia de la vida. A pesar de nuestros cantos a la comunidad, con frecuencia, no conseguimos relacionarnos bien con los demás. En el modernismo la cultura favorecía al individuo, hoy éste se siente desorientado. El modernismo era crítico, hoy se critica a los críticos. Las antinomias y las contradicciones tradicionales, hasta cierto punto, se han esfumado. La igualdad se entiende hasta cierto nivel en el que todos somos iguales, pero después hay más cosas. Es el tiempo, hoy, de la revolución en lo cotidiano, mientras antes se miraba al pasado o al futuro, hoy miramos al presente, a lo que nosotros ahora podemos hacer. Los grandes proyectos, institucionales, etc., nos dejan un tanto indiferentes. Hoy se denuncia el imperialismo de la verdad - coercitiva- y el imperialismo europeísta ${ }^{29}$.

29. «La denuncia del imperialismo de lo verdadero es una figura ejemplar del postmodernismo»: LipovetSKY, La era del vacio, 115. Cfr. nota 25, Crespi, F., 349. Según Zubiri, saber y poder tienen íntimas relaciones, como ya dijo Comte. Para Foucault, saber y poder se implican, por eso hay que estar alerta. Y tal vez así percibiremos que, con todas las cautelas: «quizás haya que renunciar también a toda una tradición que deja imaginar que no puede existir un saber sino alli donde se hallan suspendidas las relaciones de poder, y que èl saber no puede desarrollarse sino al margen de sus conminaciones, de sus exigencias y de sus intereses»: Foucault, M., Vigilar y castigar. Nacimiento de la prisión. Trad. castellana de s. XXI editores, Madrid 1984. 4. a, 34. No podemos ser fácilmente ingenuos sobre la verdad, muchas ortodoxias no son más que estrategias de poder y dominación, igual las heterodoxias a veces, por eso son tan tozudas: importa sobre todo vencer. Este imperialismo de la verdad se refleja en el imperialismo de la cultura, del bien y del mundo occidental: cfr. nota 21, Glucksmann, p. 111. Por eso este autor substituye a la vieja Europa dominante por otra más sencilla y humana, aunque parezca elemental: «Llamo Europa a una civilización que, en sus horas culturalmente más decisivas, supo prescindir de un ideal colectivo, permitiendo a cada individuo, grupo o capilla, sembrar libremente buenos sentimientos a condición de no importunar a sus semejantes». Idem, 249.

De hecho se ha confundido demasiado fácilmente el ser con la fuerza: «Podemos agregar que esta época se caracteriza sobre todo por el hecho de que el ser se da en ella como fuerza, evidencia, permanencia, grandiosidad, algo de carácter definitivo y también, probablemente, como dominio». VÁtrimo, G., El fin de la modernidad, 56. Y en el fondo, la estética filosófica, «continúa razonando atendiendo a la obra como forma presuntamente eterna y en el fondo considerando el ser como fuerza, permanencia, grandiosidad que se impone». Idem, 59. Así la postmodernidad tiene que ser «la despedida del ser metafísico y de sus caracteres fuertes» Idem, 79. Lo cual no debería entristecernos si sabemos que: «La occidentalización se realizó en primer lugar en el nivel de la extensión del dominio político y sobre todo de la difusión de modelos culturales; pero este aspecto político-cultural va acompañado por otro, de carácter científico y metodológico: el hecho de que las sociedades llamadas primitivas sean encaradas como objetos de un saber que está dominado enteramente por categorías «occidentales». Idem, 135. De ahí la preocupación de los grandes pensadores: «Una de las experiencias que Heidegger hace y expone en este diálogo con el japonés sobre el lenguaje se refiere al término $I k i$, y aquí se llega a la conclusión de que ese diálogo con las otras culturas está amenazado en su misma posibilidad por la 'europeización completa de la tierra y del hombre', como consecuencia de la cual 'aumenta el enceguecimiento' que puede destruir y hacer callar 'en sus fuentes todo lo que es esencial', todo darse originario del Wesen»: VATTIMo, G., El fin de la modernidad, 135. Así el desierto crece cada vez más a causa de la occidenta- 


\title{
III. LA ALTERNATIVA
}

\author{
La alternativa a la difícil situación descrita consiste en la vuelta a noso- \\ tros mismos: «no vayas afuera sino vuélvete a ti mismo porque en el interior
}

lización que hace imposible, con su deshumanización el auténtico diálogo que debe darse entre culturas dispares: Idem 138. Quizá la caída de esas civilizaciones maestras se deba precisamente, como dice Lyotard, a su función, ya descubierta, de ser 'narraciones de dominio': «¿Qué función tuvieron esas narraciones si no fue la de legitimar la misión que se adjudicó el hombre occidental de transformar todo el planeta a su propia imagen?»: OwENs, C., El discurso por los otros: Las feministas y el postmodernismo, HABERMAS y otros, La postmodernidad, 106. De ahí viene también la indignidad de hablar por otros y explotarlos aparentando consultarles y ayudarles. Ahí se centra también, la parte de indignidad de la misión cristiana: cfr. nota 6, Blanquart, 80-81, por su mimetismo del conquistador occidental, indigno del cristianismo auténtico. Ahora ya estamos más avisados, nuestros errores ya no tendrían excusa; Ricoeur escribe: «'Nadie puede decir lo que será nuestra civilización cuando haya conocido realmente diferentes civilizaciones por medios distintos a la conmoción de la conquista y la dominación. Pero hemos de admitir que este encuentro aún no ha tenido lugar en el nivel de un auténtico diálogo. Ésta es la razón de que nos encontremos en una especie de intervalo o interregno en el que ya no podemos practicar el dogmatismo de una sola verdad y en el que no somos todavía capaces de conquistar el escepticismo en el que nos hemos metido'. «...En la misma sintonía el arquitecto holandés Alvo Van Eyck afirmaba: «'La civilización occidental se identifica generalmente con la civilización como tal, en la suposición dogmática de que lo que no es como ella es una desviación, menos avanzada, primitiva o, como mucho, exóticamente interesante a una distancia segura' (A. Van Eyck, Forum, Amsterdam 1962)». Frampton, K., Hacia un regionalismo critico, en HABERMAS, J.-BAUdRILlARd, La postmodernidad, 45 y 46 . Tal es la discusión de la postmodernidad sobre la hegemonía cultural europea, por lo cual no es bien recibida sino insultada: «Descentrado, alegórico, esquizofrénico... Al margen de cómo decidamos diagnosticar sus síntomas, el postmodernismo suele ser tratado, tanto por sus protagonistas como por sus antagonistas, en tanto que crisis de la autoridad cultural, concretamente de la autoridad conferida a la cultura de Europa occidental y sus instituciones»: OWENS, C., El discurso por los otros, en HABERMAS, J.-BAUdRILlard, La postmodernidad, 93. Se acabó el monopolio cultural occidental.

Por desgracia, las cosas no son tan fáciles como las ven F. Fanon y otros mentores del indigenismo extremista. Según K. Frampton «existe esta paradoja: cómo llegar a ser moderno y regresar a las fuentes; cómo revivir una antigua y dormida civilización y tomar parte en la civilización universal». (RICOEuR, P., Historia y verdad). Se trata de una penosa situación, entre el empuje apolíptico de la modernización y la mítica del indigenismo, entre la nacionalidad ilustrada y el 'impulso irreal y reaccionario a regresar' al mundo preindustrial, sobre todo en este tiempo en que «el núcleo mítico-ético donde una sociedad podría arraigar, ha sido erosionado por la rapacidad del desarrollo»: FrAMPTON, K., Ib., 39. En efecto, ya hay mucha contaminación técnica y de fuerza en lo que se presenta como el ser primitivo de tal o cual pueblo, ya no reina en él su ser original, aunque lo parezca o así lo crean algunos: «(cierta) etnología está empeñada en la defensa de la autenticidad de las otras culturas creyendo que defiende esos valores propios de ellas, cuando en realidad lo que tiene ante sus ojos es sobre todo un conjunto de 'derivados' contemporáneos de la primitividad, 'formas híbridas'... supervivencias contaminadas por la modernidad, márgenes del presente que abarcan las sociedades del tercer mundo y los guetos de las sociedades industriales)» (R. Guidieri, «Les societés primitives aujourd'hui, Ch. Delachampagne y R. Maggiori, Philosopher: les interrogations contemporaines, Paris, Fayard 1980, 62.

La Unesco se funda contra el odio, el amaestramiento y la manipulación. Europa cayó en el racismo y en la adoración de sí misma; es necesario no volver a las andadas aunque ahora sea por la izquierda. Al confundirse con la civilización, los criterios y valores absolutos europeos se confundieron con la ley natural y divina. «Armados con esta certidumbre, los europeos emprendie- 
del hombre habita la verdad». Es el renacimiento en nuestra propia vocación y su más fiel cuidado lo que necesitamos con más urgencia. Se trata siempre de

ron, a fines del siglo XIX, su obra de colonización. Puesto que la Europa racional y técnica encarnaba el progreso frente a otras sociedades humanas, la conquista aparecía como la forma aún tiempo más expeditiva y más generosa de hacer ingresar a los retrasados en la orbita de la civilización... Para la propia salvación de los pueblos primitivos, era preciso reabsorber su diferencia -es decir, su atraso- en la universalidad occidental»: FinkIELKRAUT, A., La derrota, 59. Era la megalomanía del progreso. Hoy vemos que hay que abrirse a los demás, porque los más bárbaros «son los que se consideran poseedores exclusivos de la racionalidad», Idem, 61. Es preciso «terminar, de una vez por todas, con la idea a la vez egocéntrica e ingenua según la cual el hombre está enteramente refugiado en uno solo de los modos históricos o geográficos de su ser (Lévi Strauss)». Idem 63. Hay que destruir el prejuicio y ver que Europa es una variedad fugitiva y perecedera de la humanidad, no se trata de una cultura superior. "La preeminencia de esta cultura se explica por la posición dominante de la clase de donde ha salido y cuya especificidad expresa, no por la superioridad intrínseca de sus producciones o de sus valores». Idem, 64. La educación es por tanto una baza de la lucha de clases a través del cual «el grupo dominante prescribe su visión del mundo al conjunto social». Idem, 66. Entonces el monopolio de la legitimidad es la mentira del hombre del progreso y del hombre natural inmutable: «los europeos no han hecho hasta el momento más que proyectar sobre los pueblos aborígenes, sus sueños, su arrogancia y su idea de razón». Idem, 67. Así ha generalizado occidente su cultura: «al decir 'Yo soy el Hombre', ésta podía entonces con absoluta buena conciencia engullir el resto del mundo». Idem, 67. El devolver lo robado supone crear 'la equivalencia de las culturas'. Es cuando descubrimos la básica inhumanidad del humanismo. Por eso «los antihumanistas contemporáneos enseñan que el hombre no es únicamente un hermoso ideal, sino una ficción útil, un pretexto cómodamente invocado por una civilización concreta para imponer su ley». Idem, 68-69. Hay que devolver a los pueblos la dignidad expoliada por el imperialismo occidental: «así pues, la obra política de la descolonización va acompañada de una revolución en el orden del pensamiento: el hombre, ese 'concepto unitario de alcance universal' (LEACH, E., L'unité del h'homme et autres essais. Gallimard, 1980, 388), cede su lugar a la diversidad sin jerarquía de identidades culturales». Idem. 68. La tabla de valores que legitimó la servidumbre cae, «la última razón de ser de la superioridad europea se desplomaba, Occidente cesaba definitivamente de fascinar a sus víctimas». Idem, 70. A la vez se hacen añicos los tópicos sobre la psicología del indígena. Pero la tarea no es fácil, ahora acecha el colectivismo nacionalista donde la persona no pinta nada y se impone violentamente lo colectivo y la marca popular propia como una nueva cárcel. «Devueltos a sí mismos, los antiguos colonizados se descubren cautivos de su pertenencia, pasmados en la identidad colectiva que les había liberado de la tiranía y los valores europeos». Idem, 72. Aquí hay una trampa a la liberación: «Los movimientos de liberación, han secretado unos regímenes de opresión con una regularidad sin excepciones precisamente porque, a ejemplo del romanticismo político, han fundado las relaciones interhumanas en el modelo místico de la fusión, y no en el - jurídico - del contrato, y han concebido la libertad como un atributo colectivo, nunca como una propiedad individual». Idem. 75. F. FANON, Les damnés de la terre. Máspero 1961, ha sido su profeta. Así se dice que el hombre no existe y sólo los nuevos pueblos pueden hacer el nuevo hombre. El marxismo ha rechazado el romanticismo nacional y tiene grandes dificultades: «Habiendo demostrado el imperialismo soviético una voracidad por lo menos igual a la del imperialismo occidental, los Estados del Tercer Mundo y los movimientos de liberación nacional que siguen en activo rechazan cada vez con mayor frecuencia la ideología socialista en beneficio exclusivo del Volkgeist». Ib., 77-78. Así para no imitar la democracia europea se organizan dictaduras. «Para decirlo crudamente: un racismo basado en la diferencia expulsa el racismo inigualitario de los antiguos colonos». Idem, 80. Así huyendo del espíritu cosmopolita burgués (Fanon) se cae en el racismo nacionalista (hitlerianismó) (Ib., 81). Así para Fanon la verdad es lo que protege al indígena como para Barrès la verdad es lo útil a la nación 
volver a empezar, ahora empiezo, de nuevo para situarnos con nueva fe en el mundo actual y así renovar a fondo la identidad personal - interioridad-fe-; la identidad comunitaria-comunidad-caridad; la identidad de destino -misión-esperanza. Ante la crisis de identidad, de confianza y del sentido de la misión de la que nos habla Greinacher ${ }^{30}$, como de un nuevo invierno en la Iglesia, es necesario rehacer nuestras creencias y convicciones, renovar nuestro amor por los demás y nuestra confianza en el futuro de nuestra misión.

Vemos lo que ha sido destruido, al menos en gran parte:

-Los valores superiores se vuelven paradójicos. Ante los valores del narcisismo y el hedonismo, los auténticos valores se han vaciado de substancia, parece que evocan algo ridículo y que provocan más risa que respeto ${ }^{31}$.

francesa: Ib., 81,82. Hoy la raza se llama cultura propia y en ella la persona no tiene nada que hacer, Ib., 83. Es lo que se llamaba «antes Volkgeist y que hoy se llama cultura», Ib., 85. Así se cae sin saberlo en el antiguo obscurantismo. Eso sí se habla de paz y diálogo de las culturas con unos presupuestos que lo hacen imposible. Y «la cultura sirve como estandarte humanista de la división de la humanidad en entidades colectivas, insuperables e irreductibles». Idem, 90. Así se convierte en ghettos a los marginados para respetarles su propia cultura; se combate el chovinismo a la vez que se le alimenta. Idem 99. Así se destruye la cultura y la religión, pues la hospitalidad es el mínimo de la religión del amor; ahora ya ni eso, cosa que nunca había ocurrido antes: «Dios se eclipsaba, pero no 'el don, tal vez sobrenatural, de ver al hombre absolutamente semejante al hombre pese a la diversidad de las tradiciones históricas que cada cual continúa' (LevinAs, E., Difficile liberté. A. Michel 1976,232)». Idem 105.

Por tanto no hay que exagerar, ni todo es cultura, como dice el cliente-rey, ni todas las culturas son iguales, ni mucho menos. La brutalidad será siempre inhumana. La cultura no se confunde con la pulsión de cada cual en cada momento, el odio a la cultura no puede ser cultural, como no lo es el fascismo hedonista (Pasolini). Cultura es algo más que un show-businness. Quizá por eso: «Los intelectuales ya no sienten que les concierne la supervivencia de la cultura». FINKIELKRAUT, El derrota del pensamiento, 126. 185.

30. GREINACHER, N., Winter in der Kirche? Theological Quartalschrift, 3 Heft (1987) 182-

31. Cfr. nota 17, Lipovetsky, G., 162. Los intereses económicos necesitan orillar los valores morales que les impiden los negocios, y eso no se suele decir: HABERMAS, J.-BAUdRILLARD, $L a$ postmodernidad 25. Tampoco la religión puede sustituir ya a la realidad, estamos en un mundo civil: SAID, E.W., Antagonistas, públicos, seguidores y comunidad, en HABERMAS, J.-BRAUDRILLARD, J., La postmodernidad, 212, 215. No hay más que lo inmediato: «La democracia que implicaba el acceso de todos a la cultura se define ahora por el derecho de cada cual a la cultura de su elección (o a denominar cultura su pulsión del momento)». FINKIELKRAUT, La derrota, 121. No es posible, pues, la educación: «la escuela es moderna, los alumnos son posmodernos; ella tiene por objeto formar los espíritus, ellos le oponen la atención flotante del joven telespectador». FiNKIELKRAUT, La derrota, 131. La escolarización masiva prolonga y disemina a la adolescencia a todos las edades. Un delirio colectivo ha nombrado maestros a los chicos de quince años (Fellini): «El burgués ha muerto, viva el adolescente». Idem, 135. Y lo mismo se hace en la religión, vgr. en los viajes del Papa: «su espectáculo, como el de las restantes super-stars, vacía las cabezas para poder llenar mejor los ojos, y no transporta ningún mensaje, sino que los engulle a todos en una grandiosa profusión de luz y sonido. Idem, 137. El discurso es sustituido por las vibraciones y la danza. Así no se hace la justicia, los condenados de la tierra siguen muriendo de hambre y miseria pero nosotros nos sentimos bien y sabemos cantar juntos: «We are the world, we are the children. 
-Vemos hoy una desubstancialización de los principales criterios. No sirve para nada y parece ridículo todo lo oficial. La cultura racional - generalmente machista - ha terminado; hay una crisis de fondo y para resolverla hay que ir al fondo de la cuestión, a lo profundo de cada uno ${ }^{32}$. Es la conversión del hombre perdido que debe encontrar hoy un nuevo sentido a su vida. El cristianismo y la fe tienen que poner sentido donde ya no lo había por el estallido de los grandes relatos (ideales oficiales).

- Cada uno tenemos que intentar algo así como esto: no nos podemos guardar simplemente de las risas. No podemos amar al prójimo como a mí mismo si realmente no nos amamos a nosotros mismos. Por tanto debemos: rehacer nuestra vida, nuestra personalidad, nuestro yo más profundo, el sentido de nuestra vocación, rehacer la comunidad y el sentido de nuestra misión.

1. Tenemos que intentar rehacer nuestra identidad ${ }^{33}$, nuestra fe, en lo

Somos el mundo, somos los niños». Idem, 138. Ni más ni menos... Así el humanismo no es más que una broma cruel y festivalera, por tanto la religión y la ciencia que lo han avalado son fuerzas muertas: VATtiMO, G., El fin de la modernidad, 33.

32. Decía Ortega: «Lo problemático es el fondo, nuestro fondo. Nos preguntamos: ¿creo yo en el fondo eso que parezco creyendo en política, en arte, en ciencia, en amor? Porque el 'mí mismo' consistirá en lo que yo sea en el fondo" (IV, 425, 1932); se trata por tanto de una crisis radical de convicciones, de creencias que están en la UVI. No hay convicciones porque vivimos a la sombra de las mayorías en flor (Baudrillard); pegados como moscas a la realidad y a la imagen, en pleno espectáculo: «Es el fin de la interioridad y la intimidad, la excesiva exposición y trasparencia del mundo lo que le atraviesa (a la persona) sin obstáculo». BAUDRILLARD, J., El éxtasis de la comunicación, en HABERMAS, J. Otros, La postmodernidad, 196-197. El hombre vive de su imagen y lucha sin cesar por chupar cámara y permanecer en exposición (Owens, 107). Así estamos en plena descomposición de la era burguesa en la que las raíces se van perdiendo y pudriendo y lo único importante ahora parece ser la necesidad de 'sobrevivir' (Ulmer, 158).

33. Ahora la normalidad queda puesta es cuestion. No sabemos en qué debemos creer realmente. El humanismo del pasado resulta insostenible, no sabemos quienes somos, nuestra identidad se erosiana y nos duele: «Sólo en muy raros momentos desea alguno de nosotros transportarse hasta aquel extremo de sí mismo en el que sabe bien que la propia identidad comienza a tambalearse, porque la correcta organización del yo no funciona ya como tal... Sin embargo, y al mismo tiempo, cada vez nos contentamos menos con una identidad cuyo carácter ficticio, provisional y de puro compromiso salta a la vista». RovatTI, P.A., Transformaciones a lo largo de la experiencia, en Vattimo, G.- Rovatri, El pensamiento débil, 66. De este modo el antihumanismo pone en duda el valor de la conciencia que, con frecuencia, se confunde con los propios egoísmos VATTIMo, G., El fin de la modernidad, 124. Hay que ver el significado exacto de conciencia, de la misma verdad y el valor de lo fundamental. De hecho el mismo Heidegger, ya consideraba que para encontrarnos de nuevo hay que «dejar perder el ser como Grund»: Idem, 154. Estamos por tanto muy en el aire. Hay que vigilar y orar, vivir a fondo nuestra vida, renacer desde lo profundo, el abismo y el misterio, sin engañarnos con una conciencia superficial: «Tal vez a partir de aquí, una ética postmoderna podría oponerse a las éticas aún metafísicas, del 'desarrollo', del crecimiento, de lo novum (progreso) como valor último». VATTimo, G., El fin de la modernidad, 156. Quizá, por ahí, no nos vaya tan mal: «El modernismo es dominante pero está muerto... Bell ve el renacimiento religioso como la única solución. La fe religiosa unida a la fe en la tradición proporcionará individuos con identidades claramente definidas y seguridad existencial». HABERMAs, J., La modernidad, un proyecto incompleto, en Idem y otros, La postmodernidad, 24. 
que creemos realmente. Según Ortega vivimos de las creencias pero necesitamos saber si creemos realmente en lo que yo digo creer oficialmente o como dice Pablo $\dot{\mathrm{V} I}$ en $E$. Nuntiandi: «¿creemos lo que anunciamos?, ¿vivimos lo que creemos?» ${ }^{34}$. Para el cristiano la fe no es una teoría o no es fe, sino una confianza en alguien, una amistad personal con Dios. La fe debe ser 'mi fe', no simplemente la fe oficial, lo que cree la Iglesia sin que yo sepa realmente qué es lo que la Iglesia cree.

2. Hay que rehacer también la confianza en la comunidad ${ }^{35}$. Redescu-

34. Es Pablo VI el que nos plantea estas preguntas: «¿Creéis verdaderamente en lo que anunciás? ¿Vivís lo que creéis? ¿Predicáis verdaderamente lo que vivís?», Evangelii Nuntiandi, 76. El hábito ya no hace al monje; además de aparecer hay que ser. Quizá también a nosotros nos gobierna solamente el interés privado. Quizá también a nosotros nos rige únicamente el fanático y el zombie, seguimos prefiriendo el triunfo, el éxito, la fuerza a la sencillez y la humildad cristiana y agustiniana; pero no hay futuro para el cristianismo sin humildad. Se abandona, sin darse cuenta, el camino de Jesús: «Son cristianos que sin duda tienen fe, pero, si fuesen suficientemente lúcidos sobre sí mismos y si osasen decírselo, la mayor parte confesaría que se adhieren a la doctrina de su Iglesia más por disciplina que por convicción profunda; muchos reconocerían que lo que profesan públicamente supera con mucho a aquello de lo que están íntimamente convencidos o, dicho de otra manera, que lo que profesan les resulta ajeno, de ordinario. Este cisma secreto, no consentido, considerado como un mal pero no tanto como para provocar remordimiento, les aboca a una relativa inercia que echa a perder su devenir espiritual». LEGAUT, M., Creer en la Iglesia del futuro, 123-124. Se cree como por descuido, Ib. 15. Sin una vida a fondo la religion humaniza y asegura, pero nada más, y necesitamos de «una profundización en el misterio del hombre y en el misterio de Dios, gracias a una comprensión más honda de lo que tuvo que vivir Jesús para ser el que llegó a ser». Idem, 21. La mera piedad no alcanza al hombre en lo profundo de su ser y: «No une al hombre con Dios, sino que le ilusiona de que lo hace. Es una religion que desvía a sus miembros de Dios haciéndoles creer que lo alcanzan». Idem, 42. En la religión auténtica es fundamental la vida y el testimonio personal, aunque ese testimonio: «Lo hace con una discreción que contrasta con la amplitud espectacular de las manifestaciones de masas y de los medios de propaganda utilizados por las religiones de autoridad». Idem, 53. No se trata de decir solemnidades sino de presentar la vida misma: «Sólo la calidad espiritual ha de actuar sobre el destino del cristianismo para que sea fiel a su misión y se perpetúe de modo vivo», Idem, 131. ...A decir verdad, hay mucha fe implícita y crédula, el creyente vive con fe muerta: «Es un convencido más que un creyente, y por esa razón es tanto menos convincente cuanto más afirmativo. De hecho, la adhesion a la doctrina le parece que equivale a la fe, en lugar de no ser para él más que una explicación útil que, en definitiva, sólo es bienhechora si no se le concede un valor absoluto. El cristiano tiene tendencia a adherirse a la fe con rigidez y tanto más firmemente.cuanto más se prohíbe a sí mismo pensarla con espíritu e intención reflexiva». LegauT, M., Creer en, 183. Se acabó el tiempo de las excesivas facilidades sociales, económicas y políticas, es el tiempo del nuevo amor: «Entonces, la Iglesia conocerá una situación semejante a la de los últimos días de Jesús, cuando pasaba por entre las masas hostiles, o simplemente indiferentes, pero también cuando ante su mirada algunos corazones, perdidos en la multitud, se abrían al Amor». Idem 80-81.

35. Cfr. Greinacher: hay una clara falta de confianza en la comunidad tanto por parte de la jerarquía como por parte de los fieles; hay mutuas acusaciones. Hay fuertes tensiones entre individuo y comunidad (Finkielkraut, 45); de hecho la sociedad del bienestar implica: «expansión de la intimidad, erosión de las identidades sociales, desafección ideologica y politica, desestabilización acelerada de la personalidad", según lo describe Lipovetsky: BERTHOUZOZ, R., Implications éthiques des modeles actuels d'individualisme, en $L$. et $V$., 1984 (1987) 86; manda el vacío porque 
brir la confianza y la identidạd comunitaria en la Iglesia, en la congregación, en la humanidad, en la Provincia. Después de todo invierno debe haber primavera. Ante la pérdida de confianza en lo oficial y comunitario, es necesario luchar por una comunidad profundamente humana. Debe ser en la comunidad donde la vida de la persona vive su sentido, no fuera de ella; la comunidad es la congregación viva, la vocación en carne y hueso, pues es Dios quien nos ha convocado. Hay que reaccionar frente a la erosión de la vida en común.

3. También debemos redescubrir la misión; hay que redescubrir la realidad, nuestra común vocación y esperanza de futuro. Frente a la sensación de que nadie tiene ninguna misión que cumplir ${ }^{36}$, y que basta vivir bien... debemos saber que tenemos una hermosa misión y un glorioso destino en nuestra vida. Pero no hay misión, ni destino, ni moral, ni sentido, si no hay vocación

no hay ideal convincente. La sociedad está convencida de que el cristianismo desaparecerá poco a poco, no entra en el proyecto actual, es un pasado folklórico y sirve para distraerse de las cuestiones importantes: LEGAUT, M., 147. Y así será si los cristianos no nos remitimos, de verdad, a la realidad de Cristo: pues no entrará ni en los problemas del hombre ni en el misterio de Dios y se quedará en puro rito y ceremonia de confusión: «Toda la historia del cristianismo se desarrolla en torno al esfuerzo de los cristianos por recordar a Jesús de una forma real. No hay test más significativo del estado espiritual de una Iglesia que la manera como sus miembros 'hacen esto en memoria suya'». Idem, 153. Pero con frecuencia falta la auténtica adoración y la verdadera humanidad cristiana. "Con demasidada frecuencia, esa adhesión a medias, doblada de escepticismo, es suficiente para que desgraciadamente el cristiano se sienta dispensado del movimiento de la fe o, cuando menos, para que le quede desdibujada su radical originalidad». Idem 158. Así: «El cristianismo del mañana o está más arraigado que el de ayer en las profundidades de los hombres, o no será. Sólo si cumple esta condición, podrá subsistir y crecer. De otro modo, será arrancado y destruido». Idem 192. Para esta tarea la comunidad viva, la vida religiosa de calidad es imprescindible: «Sin duda alguna, estas comunidades fervientes, son más allá de los veinte siglos que las separan, la trasposición más fiel que actualmente existe de aquellas otras comunidades de los primerísimos tiempos del cristianismo en las que era fácil recordar al Maestro porque varios de sus miembros todavía habían vivido con Él». Idem 199. Así crecerá una fe viva: «Esta nueva espiritualidad se elaborará, oscura y lentamente, a través de los cristianos despiertos y vigilantes que viven perdidos y dispersos en unos entornos en los que ya no es posible ser cristiano si no se está continuamente trabajando para seguir siéndolo y para serlo cada vez más a través de una profundización en lo humano y del ejercicio de la fidelidad». Legaut, M., Creer en la Iglesia, 200.

36. «No tengo ninguna misión. Nadie tiene ninguna misión»: KUNDERA, M., La insoportable levedad del ser. Círculo de lectores, Barcelona 1984, 314. No puede haber sentido de la misión si la Iglesia, si el cristianismo es 'memoria inerte' y no memoria viva de Jesús. Ése es el mayor peligro: «el enemigo más peligroso del cristianismo sigue siendo la indiferencia, adobada de interés folklórico, que se desarrolla pacíficamente en un clima de seguridad autosuficiente y de prosperidad relativa, de despreocupación y vulgaridad contagiosas». LEGAUT, M., Creer en, 84-85. Si el cristianismo es fiel a Dios y a los hombres será recibido y acogido por un buen número de hombres buenos y se hará presente en la vida: «Ese libro de la vida leido a través del conocimiento del mensaje esencial que Jesús es en sí mismo, los encaminará hacia Dios». Idem 87. Así no caerán en la tentación de creer sólo en sí mismos, en sus métodos o en su organización, mientras el pueblo y su fe resultan anestesiadas. 
asumida personal e íntimamente en el amor incondicional como llamada inefable del Amor que es una vida desde la Vida. Sin vocación no hay moral, ni ética y nos desmoralizamos. Sin esa vivencia a fondo, vital, nos abandonamos a las vicisitudes de los tiempos, nos chantajeamos a nosotros mismos, falsificamos nuestra vida (Ortega) y caemos en la desmoralización actual de Occidente. La inmoralidad conduce irremisiblemente a la desmoralización. Por tanto hemos de convertirnos a nosotros mismos y a Dios o no tendremos remedio y pondremos a los otros a nuestro servicio, como señores (Foucault) ${ }^{37}$.

Sin esa nueva vida no se puede ser liberador porque somos esclavos de nosotros mismos y queremos dominar por encima de todos. La conversión a sí mismo lleva a la conversión a los demás. Sólo quien es señor de sí mismo puede entregar su vida a los demás gratuitamente. Por eso el talento ascético de los primeros cristianos pone también, y no sólo el mundo sabio romano ${ }^{38}$, el acento en el dominio de sí mismo, y el ser uno mismo (idiassein) como ideal del monacato. Éste descalifica el egoísmo personal y el aislacionismo de los anacoretas, criticado por san Agustín, aunque hay un ocuparse de sí mismo que es cultivo de la fe, de la amistad y de todo cuanto hace al hombre persona más verdadera y humana.

Se trata de una tarea urgente porque el tiempo pasa y se nos puede hacer tarde para cambiar de errores. Como un día tendremos que encontrarnos con nosotros mismos más vale que sea pronto. Necesitamos un arte de vivir, no sólo un ars moriendi, de rehacernos, re-formarnos, de aplicarnos a la propia vida, hacer memoria de mí y no olvidarme de mí mismo. Séneca habla de buscar la sabiduría, la paz, que el hombre vaya siendo señor de su vida y dirigirla, recogidos en paz y sosiego ${ }^{39}$. Es necesario buscar la soledad donde podamos realizar el trabajo ingente e imprescindible de rehacer los propios criterios y valores inevitables, sin los cuales la vida no es vividera ni para mí ni para los otros, ni para Dios. Ésta es una verdadera práctica social que busca un sentido, una salvación, una fe vital y auténtica sin la cual no es posible ser cristiano y menos religioso.

Para ello es necesario aconsejarse, tratar sobre la propia vida y, en momentos concretos, escuchar a otros que orienten nuestra ruta en diálogo fraterno. Eso es servir a la propia vida y darle una nueva alma. Se trata principal-

37. FouCAUlt, M., L'éthique du souci de soi comme pratique de liberté, (entretien) Concordia, 6 (19-104-105). Por lo demás: «Actualmente lo que rige la vida espiritual es el principio del placer, forma postmoderna del interés privado. Ya no se trata de convertir a los hombres en sujetos autónomos, sino de satisfacer sus deseos inmediatos, de divertirles al menor coste posible». FINKIELKRAUT, La derrota, 128.

38. Foucault, M., Histoire de la sexualité. Le souci de soi. Gallimard, Paris 1984, 84.

39. COMISIÓN EPISCOPAL DEL CLERO, Sacerdotes para evangelizar, Madrid 1987, 102-125. 
mente de los males del corazón, del pensamiento y de la sensibilidad; hay que curarse de las propias heridas y cuidarse, pues lo peor de las enfermedades del alma es que, a veces, no somos conscientes de ellas. En fin, conversión hacia uno mismo para no esclavizar a los demás: y si te encuentras mudable trasciéndete a ti mismo, hacia Dios, (san Agustín) memoria sui, memororia Dei ${ }^{40}$; encontrarse consigo mismo y encontrarse con Dios para así encontrar de nuevo al prójimo (misión).

\author{
D. NATAL \\ Estudio Teológico Agustiniano \\ Valladolid
}

40. Cilleruelo, L., «La mística de la memoria Dei en san Agustín», Estudio Agustiniano (1979) 413-448. NolaN, M., El grito del corazón. Conversión y oración hoy. Roma 1987.

Es necesario insistir en lo esencial: la renovación de la fe y la conversión no pueden ser aplazadas ni sustituidas por las ceremonias o el activismo. «A decir verdad, dirigirse al mundo con solemnes amonestaciones no es la única manera de servir a los hombres sin someterse a ellos, sin estar de algún modo a remolque suyo. La Iglesia lo logrará mucho mejor esforzándose por alcanzar lo esencial del cristianismo - lo que Jesús vivió de fundamental bajo las formas concretas de su tiempo- de manera que ese espíritu se manifieste a través de la fidelidad de sus miembros a su Maestro». LEGAUT, M., 169. Lo esencial es ser seguidores a fondo de Jesús; es la hora de Cristo, y ya no es posible «la indiferencia, el conformismo, el conservadurismo y el miedo. Se acerca la hora de los cambios tanto más importantes cuanto por más tiempo han sido rechazados. La fe de muchos, ya muy enfriada, se verá en ellos derrumbada...». ¡Ojalá la Iglesia sepa reconocerse a sí misma y no se desfonde cuando se vea desnuda y desolada, pues será precisamente entonces cuando atraiga hacia sí a todos los seres dignos de su humanidad». Idem 205. Es la hora de la cruz, se acabaron las instituciones eternas, todo dependerá de las precarias iniciativas individuales, éstas «serán las que se esfuercen por prolongar entre los hombres la misión de Jesús. Precariedad que será más aparente que real, sin embargo, puesto que entonces el cristianismo realizará una obra espiritual que sus antiguas instituciones y estructuras no hubieran podido realizar jamás, en el supuesto de que hubiesen podido conservarse. Dura etapa, semejante a la que debieron recorrer los discípulos para seguir a su Maestro hasta la cruz...» LEgAuT, Creer en la Iglesia, 205. 